\title{
Glutamatergic Signaling at the Vestibular Hair Cell Calyx Synapse
}

\author{
Soroush G. Sadeghi, ${ }^{1}$ Sonja J. Pyott, ${ }^{3}$ Zhou Yu, ${ }^{1,2}$ and Elisabeth Glowatzki ${ }^{1,2}$ \\ ${ }^{1}$ Departments of Otolaryngology, Head and Neck Surgery, and ${ }^{2}$ Neuroscience, The Center for Hearing and Balance and The Center for Sensory Biology, The \\ Johns Hopkins University School of Medicine, Baltimore, Maryland 21205, and ${ }^{3}$ Department of Otorhinolaryngology, Head and Neck Surgery, University \\ Medical Center Groningen, University of Groningen, Groningen 9700 RB, The Netherlands
}

In the vestibular periphery a unique postsynaptic terminal, the calyx, completely covers the basolateral walls of type I hair cells and receives input from multiple ribbon synapses. To date, the functional role of this specialized synapse remains elusive. There is limited data supporting glutamatergic transmission, $\mathrm{K}^{+}$or $\mathrm{H}^{+}$accumulation in the synaptic cleft as mechanisms of transmission. Here the role of glutamatergic transmission at the calyx synapse is investigated. Whole-cell patch-clamp recordings from calyx endings were performed in an in vitro whole-tissue preparation of the rat vestibular crista, the sensory organ of the semicircular canals that sense head rotation. AMPA-mediated EPSCs showed an unusually wide range of decay time constants, from $<5$ to $>500$ ms. Decay time constants of EPSCs increased (or decreased) in the presence of a glutamate transporter blocker (or a competitive glutamate receptor blocker), suggesting a role for glutamate accumulation and spillover in synaptic transmission. Glutamate accumulation caused slow depolarizations of the postsynaptic membrane potentials, and thereby substantially increased calyx firing rates. Finally, antibody labelings showed that a high percentage of presynaptic ribbon release sites and postsynaptic glutamate receptors were not juxtaposed, favoring a role for spillover. These findings suggest a prominent role for glutamate spillover in integration of inputs and synaptic transmission in the vestibular periphery. We propose that similar to other brain areas, such as the cerebellum and hippocampus, glutamate spillover may play a role in gain control of calyx afferents and contribute to their high-pass properties.

Key words: calyx; glutamate receptor; hair cell; spillover; synaptic transmission; vestibular

\section{Introduction}

In the nervous system, most synaptic terminals form bouton endings. However, there are examples of much larger, specialized presynaptic and postsynaptic endings. For example, in the auditory brainstem, the calyx of Held and the endbulb of Held are two giant presynaptic endings that form hundreds of synapses with their postsynaptic partners to faithfully transmit sound information (Ryugo and Fekete, 1982; Sätzler et al., 2002). In the vestibular sensory epithelia, the basolateral walls of type I hair cell are completely covered by a giant postsynaptic calyx ending that has no fenestrations (Goldberg, 2000; Eatock and Songer, 2011). It is highly likely that the peculiar morphology of the hair cell/calyx

\footnotetext{
Received Jan. 25, 2013; revised Sept. 11, 2014; accepted Sept. 18, 2014

Author contributions: S.G.S., S.J.P., Z.Y., and E.G. designed research; S.G.S., S.J.P., and Z.Y. performed research; S.G.S., S.J.P., and Z.Y. analyzed data; S.G.S., S.J.P., Z.Y., and E.G. wrote the paper.

This work was supported by the Vestibular Research Fund, Department of Otolaryngology-Head and Neck Surgery, Johns Hopkins School of Medicine and by a National Institute on Deafness and Other Communication Disorders Grants DC006476 and R01DC012957 to E.G., NS-050274 to the multiphoton/electrophysiology core facility, and NIDCD P30 DC005211 to the Center for Hearing and Balance Core Grant at Johns Hopkins. We thank Dr Lloyd B. Minor for supporting us in the development of a preparation of the rat crista suited for cellular physiology.

The authors declare no competing financial interests.

Correspondence should be addressed to Dr Elisabeth Glowatzki, The Johns Hopkins School of Medicine, Department of Otolaryngology-Head and Neck Surgery, The Center for Hearing and Balance, 720 Rutland Avenue, Ross 824, Baltimore, MD 21205. E-mail: eglowat2@jhmi.edu.

S. G. Sadeghi's present address: Department of Communicative Disorders and Sciences, The Center for Hearing and Deafness, State University of New York at Buffalo, Buffalo, NY 14214.

DOI:10.1523/JNEUROSCI.0369-13.2014

Copyright $\odot 2014$ the authors $\quad 0270-6474 / 14 / 3414536-15 \$ 15.00 / 0$
}

synapse has consequences for synaptic transmission. A few studies have investigated the mechanisms of synaptic transmission in the vestibular periphery. Type I hair cells contain $\sim 7-22$ individual ribbon synapses per hair cell (Lysakowski and Goldberg, 2008). There is evidence for glutamatergic synaptic transmission (Demêmes et al., 1995; Matsubara et al., 1999; Bonsacquet et al., 2006) and limited characterization of synaptic activity (Rennie and Streeter, 2006; Holt et al., 2007; Dulon et al., 2009; Contini et al., 2012; Songer and Eatock, 2013; Highstein et al., 2014). To date it remains unclear how exactly the hair cell receptor potential is converted into an afferent firing pattern at this unusual synapse.

In addition to quantal release at the type I hair cell/calyx synapse, a phenomenon termed "nonquantal" transmission occurs, in which slow changes in the calyx membrane potential mirror changes in hair cell receptor potential (Yamashita and Ohmori, 1990; Holt et al., 2007; Songer and Eatock, 2013; Highstein et al., 2014). Experimental evidence suggests both $\mathrm{K}^{+}$accumulation (Holt et al., 2007; Lim et al., 2011; Contini et al., 2012) and $\mathrm{H}^{+}$ accumulation (Highstein et al., 2014) in the synaptic cleft as possible underlying mechanisms. Alternatively, it has been suggested, but not proven experimentally, that glutamate accumulation in the synaptic cleft might lead to nonquantal postsynaptic potential changes in the calyx (Yamashita and Ohmori, 1990; Goldberg, 1996).

Here, we investigate the properties of glutamatergic synaptic transmission at the type I hair cell/calyx synapse in the excised rat crista, the sensory organ of the semicircular canals. We show that 
EPSCs at this specialized synapse have an unusually wide range of time courses, including very slow events. We provide evidence that slow components of EPSCs are partially due to glutamate accumulation and spillover. Immunolabeling of synaptic ribbons and postsynaptic glutamate receptor patches reveals that these elements are often not directly juxtaposed, providing morphological evidence consistent with postsynaptic receptor activation via glutamate spillover. Finally, we show that glutamate accumulation causes slow depolarization of the postsynaptic membrane potential, bringing it closer to AP threshold. We propose that this effect contributes to the reported increase in sensitivity and signal-to-noise ratio (Fernández and Goldberg, 1971; Sadeghi et al., 2007) of the afferent response at higher frequencies of rotation (10-20 Hz for natural head movements), making these synapses ideal "high-frequency event" detectors.

\section{Materials and Methods}

\section{Animals and preparation}

Whole-cell patch-clamp recordings were performed from type I hair cells and calyx afferent endings in the central region of cristae of 12- to 28-dold rats of either sex. In accordance with animal protocols approved by the Johns Hopkins University Animal Care and Use Committee, rats (Sprague-Dawley; Charles River Laboratories) were deeply anesthetized by isoflurane inhalation and decapitated. The inner ear tissue was removed from the temporal bone and placed into extracellular solution. The bony labyrinth was opened and part of the membranous labyrinth was dissected, including ampullae, utricle, the superior branch of the vestibular nerve that contains the afferent fibers and Scarpa's ganglion including its afferent fiber somata. The membranous labyrinth was then opened above the cristae and utricle and remaining cupulae and otoliths located on top of hair cells were removed. The preparation was secured on a coverslip under a pin, transferred to the recording chamber, and perfused with extracellular solution at a rate of $1.5 \mathrm{ml} / \mathrm{min}$. The image was visualized with a $40 \times$ water-immersion objective, differential interference contrast (DIC) optics (Examiner D1 microscope, Zeiss), additional $4 \times$ magnification and viewed on a monitor via a NC70 Newvicon camera (Dage MTI). Type I hair cell recordings were performed from the lateral wall of the hair cell, after separating the calyx from the hair cell wall with positive pressure applied by the patch pipette. For calyx recordings, the pipette was positioned at the base of the calyx.

\section{Data acquisition and analysis}

Drugs and solutions. The intracellular solution for hair cell recordings contained the following (in $\mathrm{mM}$ ): $135 \mathrm{KCl}, 3.5 \mathrm{MgCl}_{2}, 0.1 \mathrm{CaCl}_{2}, 5 \mathrm{EGTA}$, 5 HEPES, $2.5 \mathrm{Na}_{2}$ ATP, 290 mOsm, pH $7.2(\mathrm{KOH})$. The intracellular solution for calyx afferent recordings contained the following (in mM): 20 $\mathrm{KCl}, 110 \mathrm{~K}$-methanesulfonate, $0.1 \mathrm{CaCl}_{2}, 5 \mathrm{EGTA}, 5 \mathrm{HEPES}, 5 \mathrm{Na}_{2}$ phosphocreatine, 4 MgATP, 0.3 Tris-GTP, 290 mOsm, pH $7.2(\mathrm{KOH})$. The extracellular solution contained the following (in $\mathrm{mM}$ ): $5.8 \mathrm{KCl}, 144$ $\mathrm{NaCl}, 0.9 \mathrm{MgCl}_{2}, 1.3 \mathrm{CaCl}_{2}, 0.7 \mathrm{NaH}_{2} \mathrm{PO}_{4}$, 5.6 glucose, 10 HEPES, 300 mOsm, pH $7.4(\mathrm{NaOH})$. To measure the EPSC reversal potential, to block large $\mathrm{K}^{+}$currents at more positive holding potentials, in the intracellular solution $\mathrm{KCl} / \mathrm{K}$-methanesulfonate was replaced by $\mathrm{CsCl}, 280$ mOsm, pH 7.2 (CsOH). In some experiments, to increase the extracellular $\mathrm{K}^{+}$concentration to $40 \mathrm{~mm}$, equimolar $\mathrm{NaCl}$ was replaced with $\mathrm{KCl}$. Drugs were dissolved daily in the extracellular solution to their final concentrations from frozen stocks. Application of drug solutions was performed using a gravity-driven flow pipette $(100 \mu \mathrm{m}$ in diameter) placed near the recorded calyx, connected with a VC- 6 channel valve controller (Warner Instruments). Glutamate transporter blocker DLthreo- $\beta$-Benzyloxyaspartic acid (DL-TBOA), competitive glutamate receptor blocker Kynurenic acid (KynA), HCN channel (Ih) blocker 4-Ethylphenylamino-1,2-dimethyl-6-methylaminopyrimidinium chloride (ZD7288), 4-aminopyridine (4-AP) (to block low-threshold K+ channels), NMDA receptor blocker (RS)-3-(2-Carboxypiperazin-4-yl)-propyl-1phosphonic acid ((RS)-CPP), AMPA receptor blocker 2,3-dioxo-6-nitro1,2,3,4-tetrahydrobenzo[f] quinoxaline-7-sulfonamide (NBQX) and cyclothiazide (CTZ) (to remove desensitization from AMPA receptors) were purchased from Tocris Bioscience. $\mathrm{Na}^{+}$channel blocker tetrodotoxin (TTX), $\mathrm{Na}_{2} \mathrm{ATP}$, Tetraethylammonium (TEA; to block highthreshold $\mathrm{K}^{+}$channels), KCNQ channel blocker XE-991, and $\mathrm{BaCl}_{2}$ (to block inward rectifier $\mathrm{K}^{+}$channels) were purchased from Sigma-Aldrich.

As the basolateral walls of type I hair cells are covered by afferent calyx terminals, the question arose whether the perfused extracellular solutions did reach the synaptic cleft. When the preparation was perfused with NBQX, an AMPA receptor blocker, synaptic activity was abolished, demonstrating that the synaptic cleft between type I hair cell and calyx afferent was accessible for perfusion.

Data acquisition. Recording pipettes were fabricated from $1 \mathrm{~mm}$ borosilicate glass (WPI). Pipettes were pulled with a multistep horizontal puller (Sutter), fire polished, and coated with Sylgard (Dow Corning). Pipette resistances were 7-10 $\mathrm{M} \Omega$ for calyces and 3-5 $\mathrm{M} \Omega$ for hair cells. Recordings were performed either at $25-27^{\circ} \mathrm{C}$ (room temperature) or at $35-37^{\circ} \mathrm{C}$ (close to body temperature). All measurements were acquired using pCLAMP 10.2 software in conjunction with a Multiclamp 700B amplifier (Molecular Devices), digitized at $50 \mathrm{kHz}$ with a Digidata 1322A, and low-pass filtered at $10 \mathrm{kHz}$. In current-clamp mode, bridge balance and pipette capacitance neutralization were adjusted. In both voltageclamp and current-clamp, voltages were corrected off-line for the measured liquid junction potential of $-9 \mathrm{mV}$ for calyx recordings and of -4 $\mathrm{mV}$ for hair cell recordings.

Cell membrane and recording parameters. Membrane capacitance $\left(C_{\mathrm{m}}\right)$, membrane resistance $(R \mathrm{~m})$, and series resistance $(R \mathrm{~s})$ were calculated from the average current response (50 repetitions) to $10 \mathrm{mV}$ hyperpolarizing steps from -79 to $-89 \mathrm{mV}$ (Vstep). $C_{\mathrm{m}}$ was calculated as $C_{\mathrm{m}}=\mathrm{Q} /$ vstep, where $\mathrm{Q}$ is the amount of charge stored on the membrane capacitor calculated as the area under the transient current response to the voltage step. $R \mathrm{~m}$ was calculated from the steady-state current response (Isteady) as $R \mathrm{~m}=V$ step/Isteady. With $R \mathrm{~m}>>>R \mathrm{~s}, R$ s could be calculated as $R \mathrm{~s}=V$ step/Ipeak, where Ipeak is the peak current of the transient current response to the voltage step. $C_{\mathrm{m}}$ was $28.1 \pm 5 \mathrm{pF}, R \mathrm{~m}$ was $102.5 \pm 7.6 \mathrm{M} \Omega$, and $R$ s was $26 \pm 2 \mathrm{M} \Omega(n=33)$. Recordings with $R \mathrm{~s}>40 \mathrm{M} \Omega$ were discarded.

To test for the effects of Rs errors in the recording configuration, in eight calyx afferent recordings, EPSCs were recorded before and after $R s$ compensation $(85-95 \%)$ in $5.8 \mathrm{~mm} \mathrm{~K}^{+}$extracellular solution at a holding potential of $-103 \mathrm{mV}$. The large negative holding potential resulted in larger EPSC amplitudes and improved signal-to-noise ratio. For this dataset, with an average holding current of $337 \mathrm{pA}$, the estimated voltage error changed from 9.3 to $1.3 \mathrm{mV}$ after Rs compensation. The pooled EPSC amplitude distributions for the eight recordings showed an extended tail with larger EPSC amplitudes after Rs compensation. The average EPSC amplitude doubled with $R$ s compensation, from $26.4 \pm 4.9$ to $58.4 \pm 12 \mathrm{pA}(n=8$, paired $t$ test, $p=0.02)$.

Regarding EPSC kinetics, for the pooled EPSCs from eight calyces, no significant difference was observed before and after Rs compensation, with the average $10-90 \%$ rise times of $2.2 \pm 0.9 \mathrm{~ms}$ ( $n=1397$ EPSCs) and $1.5 \pm 0.4 \mathrm{~ms}(n=1347$ EPSCs; paired $t$ test, $p=0.4)$ and EPSC decay time constants of $28.3 \pm 9.4 \mathrm{~ms}$ and $22.5 \pm 8.7 \mathrm{~ms}$ (paired $t$ test, $p=0.4$ ), respectively. Note that the distributions of $10-90 \%$ rise time and decay time constant showed a slight shift to the left after Rs compensation. For decay times, mainly the number of EPSCs with decay times $<2 \mathrm{~ms}$ increased. This was expected; the time constant of the voltage-clamp was $0.7 \mathrm{~ms}\left(C_{\mathrm{m}} \times R \mathrm{~s}\right)$ without $R \mathrm{~s}$ compensation and $0.1 \mathrm{~ms}$ with $R$ s compensation, suggesting that only values $>\sim 1.4 \mathrm{~ms}$ could be measured correctly without $R$ s compensation and $>\sim 0.2 \mathrm{~ms}$ with $R$ s compensation.

Accordingly, for studying EPSC amplitudes, only recordings with $R s$ compensation were used, whereas for investigating decay time constants, recordings without $R$ s compensation were included, as the effects regarding spillover investigated in this study concerned mainly the slow components of EPSCs, with values much slower than the estimated clamp speed, even without $R$ s compensation.

Estimating the hair cell membrane potential. Efflux of $\mathrm{K}^{+}$from the hair cells and/or the calyx ending could additionally affect $\left[\mathrm{K}^{+}\right]$in the synaptic cleft and subsequently affect hair cell and/or calyx membrane potential (Lim et al., 2011). For this study, calyx membrane potentials were 
recorded with the synaptic cleft intact. However, for recording hair cell membrane potentials, the synaptic cleft was opened to allow for the patch pipette to reach the hair cell lateral wall, possibly resulting in a loss of $\mathrm{K}^{+}$ accumulation due to $\mathrm{K}^{+}$efflux from the hair cell and/or calyx. Second, in vivo, the stereocilia bundles are exposed to endolymph (high in $\left[\mathrm{K}^{+}\right]$) and the hair cell bodies are exposed to perilymph (high in $\left[\mathrm{Na}^{+}\right]$) whereas in vitro, hair cell bodies and stereocilia are bathed in perilymphlike solution. Regarding mechano-transduction, $\mathrm{Na}^{+}$-influx should substitute for $\mathrm{K}^{+}$-influx in vitro. However, fewer transduction channels may be open at rest, due to a higher $\left[\mathrm{Ca}^{2+}\right]$ in the perilymph-like solution compared with endolymph, resulting in a more negative resting membrane potential in vitro compared with in vivo (Farris et al., 2006). The "endovestibular" potential, as measured between endolymph and perilymph space in vivo is small, $(2-5 \mathrm{mV})$ compared with the large endocochlear potential ( $\sim 80 \mathrm{mV}$; Smith et al., 1958; Schmidt, 1963) and therefore its possible loss in vitro is of minor concern.

Holding potential. At a fairly negative holding potential of $-103 \mathrm{mV}$, the holding current was typically $\sim 300 \mathrm{pA}$ and holding currents up to $\sim 500 \mathrm{pA}$ were considered acceptable. To assure that a large component of the holding current was due to active ion channels and not to unspecific leak, a mixture of blockers was applied to test the possible contribution of different ion channels (100 $\mu \mathrm{M}$ XE-991, 10-30 mM TEA, 2-4 mM 4-AP, $2 \mathrm{mM} \mathrm{BaCl}_{2}, 50 \mu \mathrm{M} \mathrm{ZD} 7288$ to block KCNQ channels, potassium channels, inward rectifiers, and $\left.I_{\mathrm{h}}\right)$. Such a mixture reduced holding currents by $>50 \%$ ( $n=9$, control: $433 \pm 33$ pA, with blockers: $205 \pm 35$ $\mathrm{pA}$, paired $t$ test, $p<0.0002)$.

Second, if large holding currents were indicative of large unspecific leak currents, one would predict that in "leaky recordings" the measured resting membrane potentials were less negative. Resting membrane potentials were compared for calyces with holding currents between 0 to $-500 \mathrm{pA}$ in $100 \mathrm{pA}$ bins. Average resting membrane potentials were $-69.8 \pm 2.1 \mathrm{mV}(n=23),-70.7 \pm 1.9 \mathrm{mV}(n=27),-69.1 \pm 1.2 \mathrm{mV}$ $(n=34),-67.6 \pm 0.8 \mathrm{mV}(n=43)$, and $-66.2 \pm 1.8 \mathrm{mV}(n=46)$, respectively, and were not different from each other (ANOVA, $p=0.07$ ), suggesting that recordings with large holding currents were qualitatively as good as recordings with smaller holding currents.

Data analysis. The EPSC decay time was either fit with one or two exponentials. For the fit with two exponentials, the following equation was used:

$$
\mathrm{f}(\mathrm{t})=\mathrm{A}_{1} \times\left[\exp \left(-\mathrm{t} / \tau_{1}\right)\right]+\mathrm{A}_{2} \times\left[\exp \left(-\mathrm{t} / \tau_{2}\right)\right]
$$

where $\tau_{1}$ and $\tau_{2}$ are the "faster" and "slower" $\tau_{\text {decays }}, A_{1}$ and $A_{2}$ are the respective amplitudes, and $t$ is time.

Data were analyzed using Clampfit (Molecular Devices), MiniAnalysis (Synaptosoft), and MATLAB (MathWorks) software. EPSCs were detected using a routine in Minianalysis, with a threshold set at three times the value of the root mean square of the baseline noise. Events that showed summation were identified by eye and not included in the analysis. For $\tau_{\text {decay }}, 10-90 \%$ of the decay times were fit. Data are reported as mean \pm SE. Significance was measured by paired or unpaired $t$ test for comparison of two parameters. For comparisons of more than two conditions, one-way ANOVA with Tukey's HSD post hoc test was used. Level of statistical significance was set at $\alpha=0.05$.

\section{Labeling of fibers with biocytin}

For calyx recordings, $0.3 \%$ biocytin was added to the intracellular solution. After recording, tissue was fixed in $4 \%$ paraformaldehyde overnight at $4^{\circ} \mathrm{C}$ and then kept in PBS. The tissue was quenched in $1 \%$ hydrogen peroxide for $10 \mathrm{~min}$, permeabilized in $2 \%$ Triton X-100 in PBA for $1 \mathrm{~h}$, incubated for $2 \mathrm{~h}$ using VECTASTAIN ABC kit (Vector Laboratories), and finally in $0.1 \% \mathrm{OsO}_{4}$ for $30 \mathrm{~s}$. In between steps, the tissue was rinsed three times $(10-30 \mathrm{~min}$ each $)$ in PBS. After a final PBS rinse $(3 \times 15$ min), the tissue was mounted on a slide with Mowiol mounting solution. A Nikon E600 compound microscope with $40 \times$ magnification was used to inspect the tissue for the number of labeled calyces.

\section{Immunofluorescence and microscopy}

Excised whole-tissue preparations of horizontal and anterior cristae of 17 - to 21 -d-old rats were immediately transferred from PBS to $4 \%$ para- formaldehyde in PBS, fixed for $50 \mathrm{~min}$, and then rinsed three times in PBS. Cochlear organs of Corti from equivalently aged rats were excised and fixed as described previously (McLean et al., 2009). For both vestibular and cochlear preparations, samples were first incubated in blocking buffer (PBS with 5\% normal goat serum, 4\% Triton X-100, and 1\% saponin) for 1-2 h. Preparations were then incubated in primary antibody diluted in blocking buffer overnight. Samples were rinsed three times 10 min each in PBS with $0.2 \%$ Triton X-100 (PBT) before incubation in the appropriate secondary antibody diluted 1:500 in blocking buffer for $2 \mathrm{~h}$. Immunofluorescent staining was performed using the following antibodies: mouse monoclonal (IgG1) anti-CTBP2 (612044, 1:300; BD Bioscience), rabbit polyclonal anti-GluR2/3 (AB1506; 1:100; Millipore), mouse monoclonal (IgG2A) anti-PSD95 (75-028, 1:300; NeuroMab), mouse monoclonal (IgG2A) anti-TuJ (neuronal class III $\beta$-tubulin; MMS-435P, 1:300, Covance), and mouse monoclonal (IgG1) anti-TuJ (MAB1637, 1:300, Millipore). Secondary antibodies, AlexaFluor 488 goat anti-mouse IgG1 (A21121), AlexaFluor 488 goat antimouse IgG2 $\mathrm{A}$ (A21131), AlexaFluor 647 goat anti-mouse IgG1 (A21240), AlexaFluor 647 goat anti-mouse IgG2 ${ }_{\mathrm{A}}$ (A21241), and AlexaFluor 568 goat anti-rabbit IgG (A11011) were purchased from Molecular Probes (Life Technologies). Preparations were again rinsed three times $10 \mathrm{~min}$ each in PBT, and then once for $10 \mathrm{~min}$ in PBS before mounting on glass slides in Vectashield mounting medium (Vector Laboratories). All incubation and rinses were performed on a rocking table at room temperature. The antibodies used in this study were chosen because their specificity has been characterized previously, and in all cases, experiments performed in the absence of primary antibody showed no immunoreactivity.

Fluorescence images were acquired using an Olympus Fluoview FV1000 confocal microscope with a $60 \times$ Olympus PlanoApo oilimmersion lens (NA 1.42) under the control of the Olympus Fluoview FV1000 v2.1 software. $z$-Stacks (46-100 optical sections) through the majority of the preparation were collected in $0.44 \mu \mathrm{m}$ steps. The step size (optical section thickness) was determined by stepping at half the distance of the theoretical $z$-axis resolution (the Nyquist sampling frequency). Images were acquired in a $1024 \times 1024$ raster $(x=y=0.207$ $\mu \mathrm{m} /$ pixel) at subsaturating laser intensities for each channel. Images are presented as $z$-projections through a subset of the collected optical stack. All quantitative image analysis was performed on the raw image stacks, without deconvolution, filtering, or gamma correction.

To determine their total number and relative location, immunolabels were detected automatically using the Spots function in the Imaris 6.4 three-dimensional (3D) image visualization and analysis software (Bitplane). Image files were resampled upon opening in Imaris to include a specific 3D ROI that included the calyces to be analyzed. Automatically detected immunolabels were verified by eye by rotating the $3 \mathrm{D}$ image, and immunolabels not contained within the inner face of calyces were manually removed. Distances of CTBP2, GluR2/3, and PSD95 labels were calculated from the $x, y$, and $z$ coordinates of immunolabels.

\section{Results}

\section{Recordings from calyx afferent terminals in the crista of semicircular canals}

To study the properties of synaptic transmission between type I vestibular hair cells and their afferent calyx endings, a method was established to dissect the rat inner ear and excise the cristae, the sensory organs of the semicircular canals, along with the utricle, nerve fibers and Scarpa's ganglion (Fig. 1A1). Recordings were performed from the central zone of the crista at postnatal days (P)12-P28, because type I hair cells have acquired their characteristic morphological and electrophysiological properties by P12 (Rüsch et al., 1998; Hurley et al., 2006). Furthermore, the percentage of type I hair cells with morphologically fully developed calyces increases during development (Favre and Sans, 1979 ) and reaches a plateau at $\sim$ P10 in the central zones of vestibular end organs (Rüsch et al., 1998), which contain higher numbers of type I hair cells and calyx afferent endings compared 


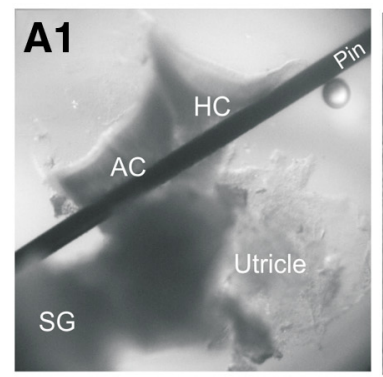

B

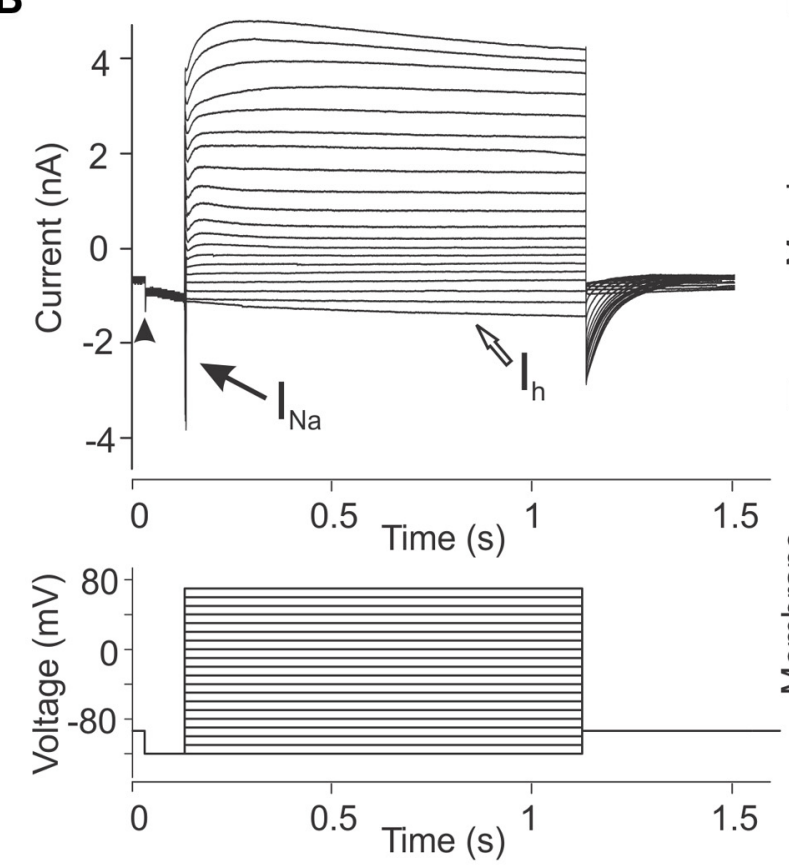

$\mathbf{F}$
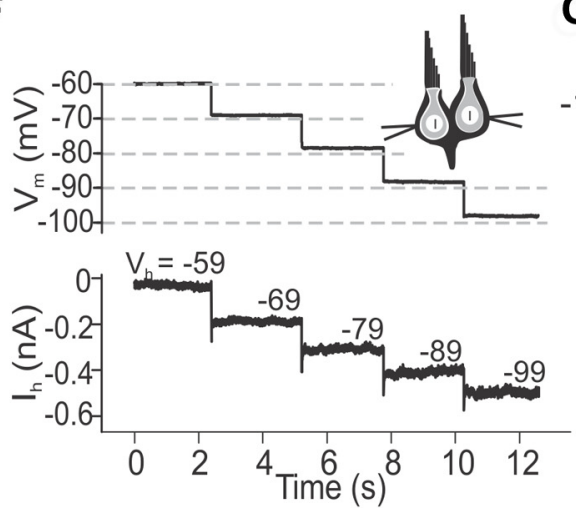

G
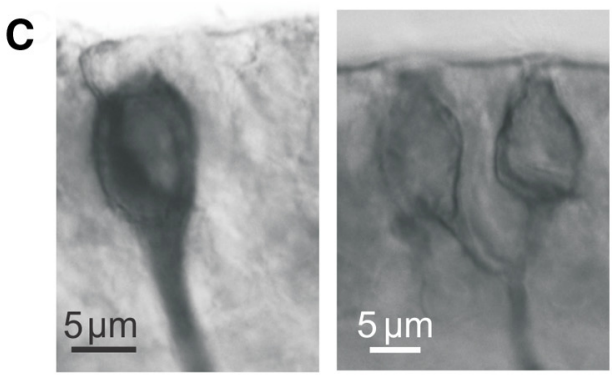

D

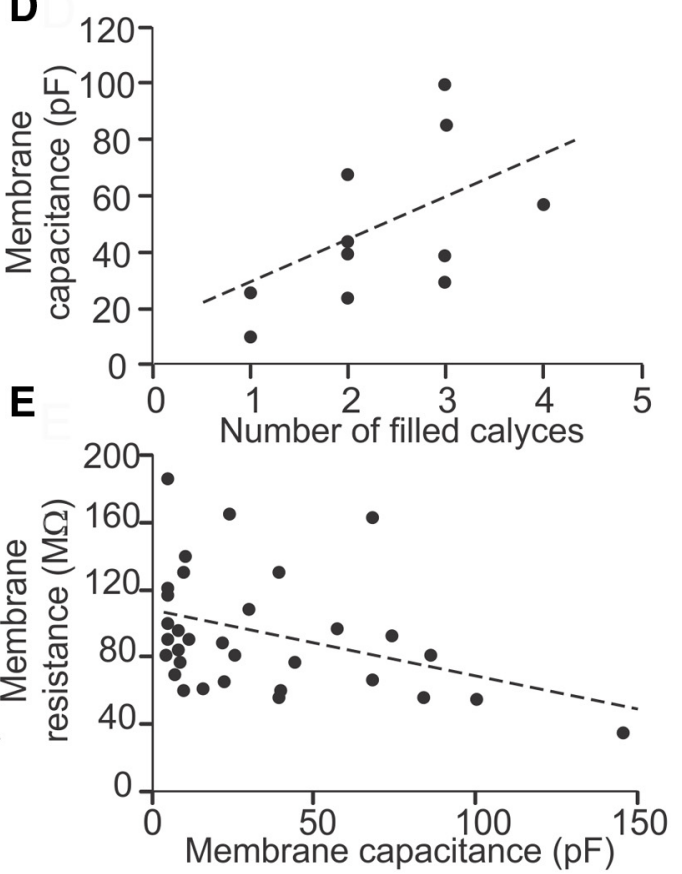

$\mathbf{H}$

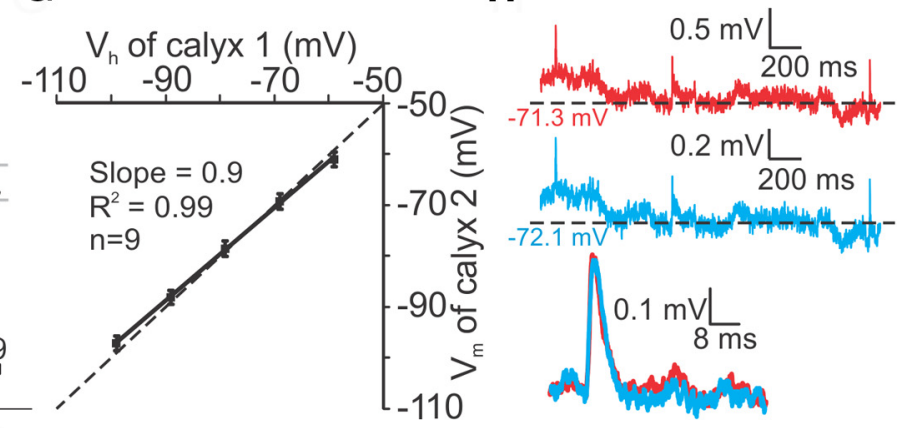

Figure 1. Calyx afferents visualized and recorded from the rat vestibular periphery. $\boldsymbol{A}$, Whole-tissue preparation of anterior and horizontal canal cristae (AC and $\mathrm{HC}$ ) held under a pin, along with the utricle and Scarpa's ganglion (SG; $A$ 1). Using DIC optics, calyces in the central zone were visualized as bright thick lines around type I hair cells (marked by I in A2). Recordings were made at the base of the calyx (arrow). Scale bar, $10 \mu \mathrm{m}$. B, Response of a calyx to the voltage step protocol (initial holding voltage of -103 and $10 \mathrm{mV}$ steps between -129 and $61 \mathrm{mV}$ ). Calyx recordings exhibited large $\mathrm{Na}^{+}$inward currents (black arrow), delayed rectifier type outward currents during depolarizing voltage steps, and slowly deactivating currents during hyperpolarizing steps (arrowhead) and hyperpolarization-activated currents ( $I_{\mathrm{h}}$; open arrow). $\boldsymbol{C}$, Biocytin fills of example calyx recordings. $\boldsymbol{D}$, Calyces had a wide range of $C_{\mathrm{m}}$ that increased with the number of labeled calyces. $\boldsymbol{E}$, Calyces showed a wide range of $R \mathrm{~m}$ that decreased with increasing $C_{\mathrm{m}}$. Thirty-three calyces, including 11 calyces from $\boldsymbol{D}$. $\boldsymbol{F}$ - $\boldsymbol{H}$, Double-recordings from complex calyces. $\boldsymbol{F}$, In one calyx, the membrane was clamped to a holding potential between -59 and $-99 \mathrm{mV}$ in $10 \mathrm{mV}$ steps, while in the other calyx the membrane potential was measured in current-clamp. $\mathbf{G}$, In nine double-recordings from complex calyces, the difference between holding potential $\left(V_{h}\right)$ of calyx 1 and the measured membrane potential of calyx $2\left(V_{m}\right)$ was $<4 \%$. $\boldsymbol{H}$, Example double-recording from two calyces within a complex calyx in current-clamp. Membrane potentials of both calyces were similar and EPSPs were similarly shaped (bottom).

with peripheral zones (Lysakowski and Goldberg, 2008). When viewed at larger magnification with DIC optics, calyces were visible as thickenings around type I hair cells, which were identified by their typical morphology with a smaller apical diameter (the so-called "neck") of the hair cell (Fig. 1A2). Recordings were performed at the base of the calyx, close to where the calyx transitions into the vestibular nerve fiber (Fig. 1A2, arrow). During whole-cell recordings, the average resting membrane potential of calyces was $-68.1 \pm 0.5 \mathrm{mV}(n=173)$. Voltage step protocols were used to distinguish calyx recordings from type I hair cell 
recordings (Fig. 1B). Calyx recordings exhibited large $\mathrm{Na}^{+}$inward currents with amplitudes of several nanoamperes, whereas hair cells showed smaller or no $\mathrm{Na}^{+}$currents (Wooltorton et al., 2007). Calyx recordings displayed delayed rectifier type outward currents during depolarizing voltage steps and slowly deactivating currents during hyperpolarizing steps from -103 to -129 $\mathrm{mV}$ (Fig. $1 B$, arrowhead), most likely due to KCNQ and erg channel activation (Hurley et al., 2006). Similar to auditory afferent fibers (Yi et al., 2010), a hyperpolarization-activated current $\left(I_{\mathrm{h}}\right)$ was also present in calyx afferent fibers (Meredith et al., 2012; Horwitz et al., 2014).

Afferent fibers with calyx endings can innervate an individual type I hair cell or form a "complex calyx" that contacts a group of hair cells with several calyces (Fernández et al., 1988). Additionally, "dimorphic" afferent fibers form calyx endings and also send branches off to form bouton endings onto type II hair cells. To investigate their morphology, some afferent fibers were filled with biocytin during recordings. In 13 such recordings, 11 showed calyx endings (Fig. 1C) and two showed calyx endings and additional branches, most likely ending in boutons. One to four calyces were counted to connect to individual fibers. Membrane capacitance $\left(C_{\mathrm{m}}\right)$ generally increased as the number of filled calyces per fiber increased (Fig. $1 D$ ). By dividing $C_{\mathrm{m}}$ by the number of filled calyces per fiber, $C_{\mathrm{m}}$ per individual calyx was estimated at $19 \pm 3 \mathrm{pF}$ for these neurons $(n=11)$. For 33 afferent calyx recordings, the average $C_{\mathrm{m}}$ was $28.1 \pm 5 \mathrm{pF}$ (range: $5-145$ $\mathrm{pF}$ ) and the average $R \mathrm{~m}$ was $102.5 \pm 7.6 \mathrm{M} \Omega$ (range: $35-185$ $\mathrm{M} \Omega$ ). The large ranges of $C_{\mathrm{m}}$ and $R \mathrm{~m}$ were due to the varying number of calyces (Fig. $1 D$ ). As expected, $C_{\mathrm{m}}$ and $R \mathrm{~m}$ were inversely related (Fig. 1E).

Because the recording electrode was positioned at the base of a calyx, in the presence of complex calyces, it most likely measures events generated from all calyces that contact an individual fiber. To investigate whether individual calyces within a complex calyx are exposed to the same voltage-clamp conditions, or whether "space clamp" problems occur, recordings were performed simultaneously from the lateral membranes of two calyces that were visually identified as part of a complex calyx. At one electrode, the holding potential was stepped from -59 to $-99 \mathrm{mV}$ in $10 \mathrm{mV}$ steps, while at the same time at the second electrode, voltage changes in the neighboring calyx were monitored (Fig. $1 F$ ). In nine paired recordings, the difference between command and measured potential was $<4 \%$, confirming that space clamp errors had minimal effects on recordings from complex calyces (Fig. $1 G$ ).

To investigate whether passive properties in complex calyces affected synaptic events traveling along the calyx membrane to the recording site, EPSPs recorded by two electrodes positioned at different calyces belonging to a complex calyx were compared (in six double recordings; Fig. $1 H$ ), similar to studies performed in neural dendrites (Magee and Cook, 2000). Membrane potentials recorded at the two electrodes were similar, differing by $<0.02 \mathrm{mV}$, and EPSPs were close to identical, suggesting that synaptic events were not substantially distorted by passive cable properties when traveling to the recording site.

In summary, control experiments suggest that the waveforms of synaptic events recorded from a single or complex calyx afferent are not subject to substantial errors. However, the possibility still remains that a small percentage of synaptic events might be generated in distant branches of the afferent fiber that were unaccounted for and the waveform of such events might be affected by space clamp errors and passive membrane properties.

\section{Amplitude distributions of AMPA receptor-mediated EPSCs in calyx afferent fibers}

EPSCs were observed in 27\% (46 of 173) of calyx afferent recordings. The large percentage of "silent synapses" is not surprising, as the average hair cell membrane potential recorded under similar conditions was found to be quite negative, $-70.5 \pm 1.7 \mathrm{mV}(n=$ 10 ), suggesting a low probability of release. The recorded hair cell membrane potential reflects the experimental conditions (see Materials and Methods for further explanation) and the high spontaneous firing in type I afferent fibers that has been found in vivo (Yang and Hullar, 2007; Lasker et al., 2008) may be due to a more positive hair cell membrane potential under in vivo conditions. As expected, when the hair cell was depolarized, with elevated $\left[\mathrm{K}^{+}\right]$or ATP in the extracellular solution, EPSCs were activated in most silent calyx recordings. Similarly, a recent study reported that in utricular calyx recordings some afferents did not show synaptic activity, but exhibited EPSCs when the hair bundle of the presynaptic hair cell was deflected (Songer and Eatock, 2013).

EPSCs were completely $(n=11)$ and reversibly $(n=4)$ blocked by the specific AMPA receptor blocker NBQX (10 $\mu \mathrm{M}$; Fig. 2A). The current voltage relation of average EPSCs was close to linear and reversed at $\sim 0 \mathrm{mV}$ (4 calyx recordings; Fig. $2 \mathrm{~B}, \mathrm{C}$ ). EPSCs often showed decay times with a faster and a slower component and therefore, were tested for a possible contribution from NMDA receptors. Experiments were performed in $0 \mathrm{Mg}^{2+}$ extracellular solution, to relieve $\mathrm{Mg}^{2+}$ block of NMDA receptors, and with added $40 \mu \mathrm{M}$ D-serine, a cofactor of NMDA receptors. Under these conditions, application of the NMDA receptor blocker CPP $(20 \mu \mathrm{M})$ had no effect on the average EPSC waveform, neither at a negative $(-80 \mathrm{mV})$ nor at a positive $(+60 \mathrm{mV})$ holding potential (Fig. 2D). When the EPSC decay time was fit with two exponentials, neither of the decay time constants, $\tau_{1 \text { decay }}$ or $\tau_{2 \text { decay }}$, were affected by CPP (Table 1$)$. Together, these findings suggest that AMPA receptors mediate the observed EPSCs at type I hair cell/calyx synapses.

EPSC amplitude distributions showed some variability between recordings. Figure $2 E$ shows two representative EPSC amplitude distributions that span over the range of values found in 15 recordings (Fig. $2 F$ ). Both distributions were well fit with a Gaussian and additionally exhibited a small tail at larger amplitudes. Peak amplitudes for these two distributions were $20 \mathrm{pA}$ (black) and 93 pA (green), with coefficients of variation of 0.44 and 0.31 (holding potential, $-103 \mathrm{mV}$ ). For 15 recordings, on average $>90 \%$ of EPSCs were smaller than 150 pA (Fig. $2 F$, dashed trace) and the mean and median EPSC amplitudes were $80.8 \pm 1.0$ and $74.3 \mathrm{pA}$, and the resulting mean and median conductances were 784 and $721 \mathrm{pS}(n=1865$ EPSCs, pooled from 15 recordings).

Variability between EPSC amplitude distributions of individual calyces could be caused by a number of mechanisms, for example by variations in hair cell membrane potential and subsequent changes in calcium influx, affecting the level of multivesicular release (Wadiche and Jahr, 2001) as it has been shown at other ribbon synapses (Singer et al., 2004; Li et al., 2009). To test whether a similar mechanism might apply here, EPSC amplitudes were compared at two different levels of hair cell depolarization, in extracellular solution with either 5.8 or $40 \mathrm{~mm} \mathrm{~K}^{+}$. In type I hair cell recordings, switching from 5.8 to $40 \mathrm{mM} \mathrm{K}^{+}$external solution, depolarized the hair cell membrane potential by $\sim 40$ $\mathrm{mV}$, from $-70.5 \pm 1.7 \mathrm{mV}$ to $-29.6 \pm 1.5 \mathrm{mV}(n=10)$. In afferent fiber recordings, when changing from 5.8 to $40 \mathrm{~mm} \mathrm{~K}{ }^{+}$ external solution, EPSC rates increased from $1.2 \pm 0.5 \mathrm{EPSCs} / \mathrm{s}$ to 
A
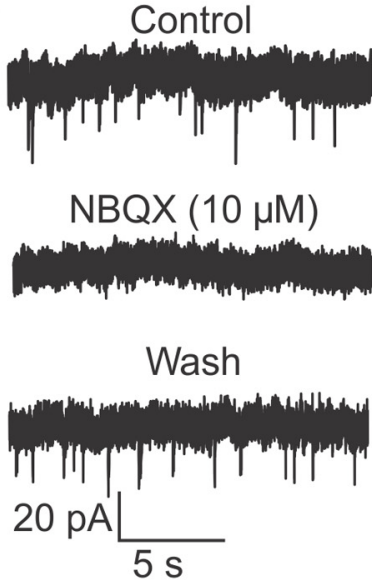

D

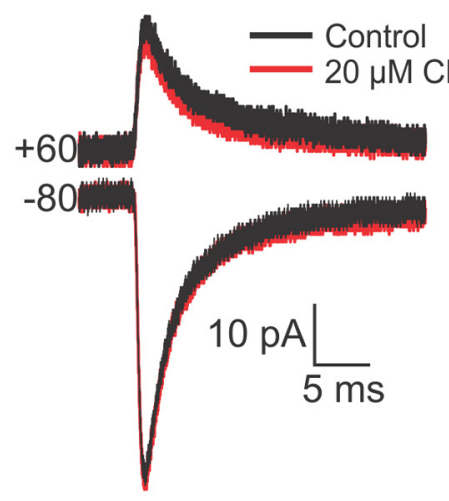

G

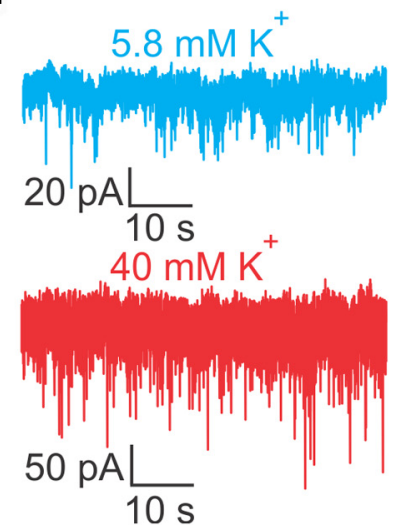

B

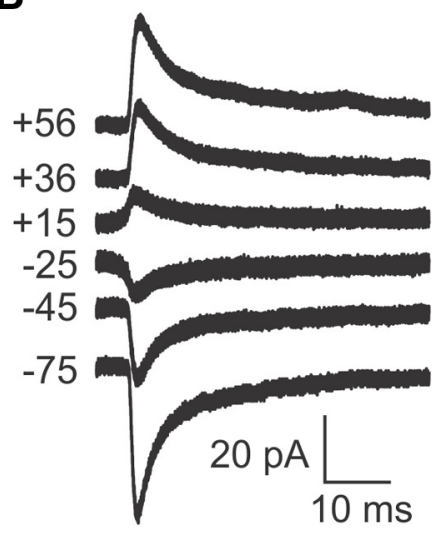

E

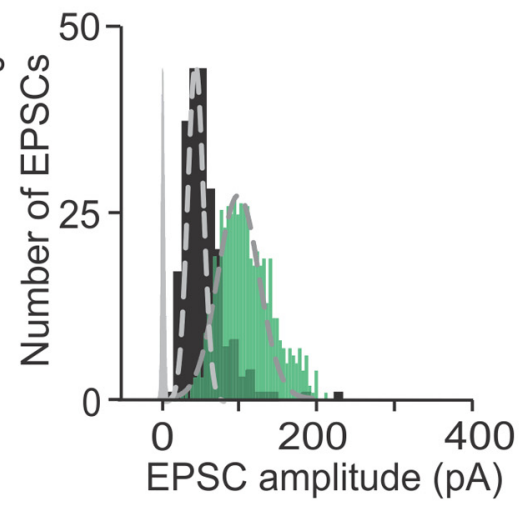

H

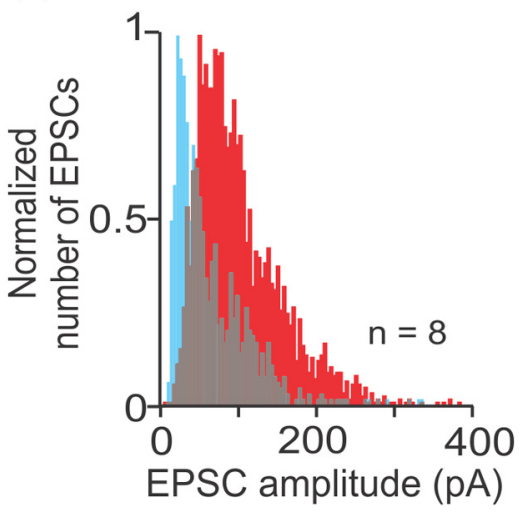

C

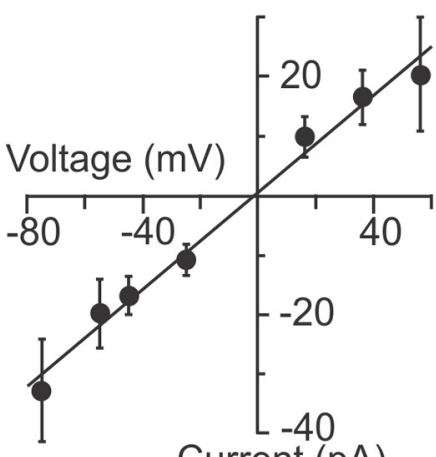

Current (pA)

F

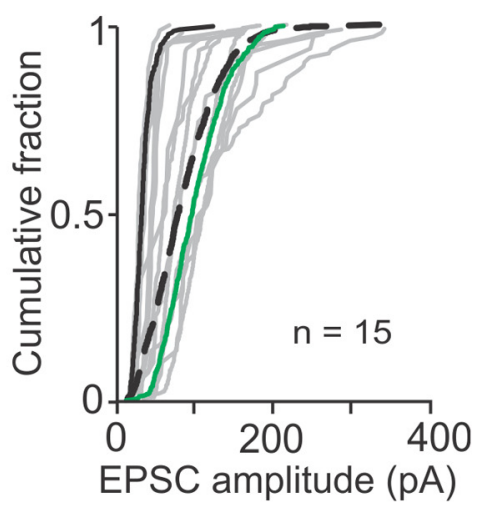

I

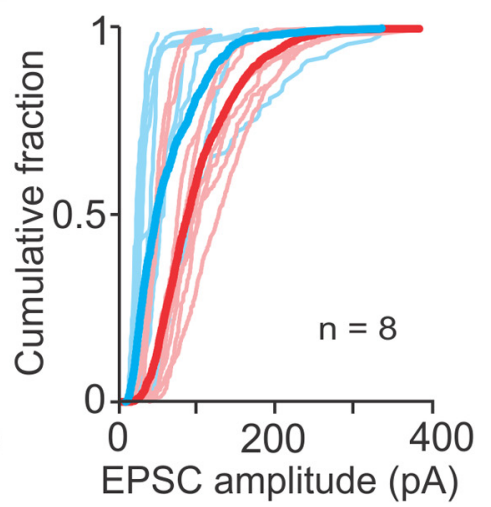

Figure 2. EPSC amplitude distributions recorded from vestibular calyces. $A$, EPSCs are mediated by AMPA receptors, as shown by complete and reversible block by the AMPA receptor blocker NBQX $(10 \mu \mathrm{M})$. External solution with $5.8 \mathrm{~mm} \mathrm{~K}^{+}$; holding potential of $-103 \mathrm{mV} . \mathbf{B}$, Calyx recording with average EPSCs at different holding potentials (indicated on the trace in $\mathrm{mV}$ ). C, Current voltage relation of average EPSCS (4 recordings) is close to linear and reverses at $\sim 0 \mathrm{mV}$. D. The NMDA receptor blocker CPP (20 $\mu \mathrm{m})$ had no effect on the EPSC waveform at positive or negative holding potentials (indicated on traces). $\boldsymbol{E}$, Two example EPSC amplitude distributions were close to Gaussian (dashed lines), with small tails toward larger values. Baseline noise distribution in gray. $\boldsymbol{F}$, Cumulative fraction plots of EPSC amplitudes for 15 calyces (gray) and their average (dashed black). Black and green lines correspond to calyces shown in E. G, EPSC amplitudes and rate increased during application of $40 \mathrm{~mm} \mathrm{~K}^{+}$external solution. $\boldsymbol{H}$, Normalized cumulative fraction plots of EPSC amplitudes pooled from 8 calyces in $5.8 \mathrm{~mm} \mathrm{~K}^{+}$(blue) and in $40 \mathrm{~mm} \mathrm{~K}^{+}$external solution (red). I, Cumulative fraction plots of EPSC amplitudes for eight calyces in $5.8 \mathrm{~mm} \mathrm{~K}^{+}$(individual recordings: light blue; average distribution: blue) shifted to the right in $40 \mathrm{~mm} \mathrm{~K}^{+}$external solution (individual recordings: light red; average distribution: red).

$15.3 \pm 3.3 \mathrm{EPSCs} / \mathrm{s}$ ( 8 calyx recordings, paired $t$ test, $p=0.0005$ Fig. 2G). EPSCs recorded in $40 \mathrm{mM} \mathrm{K}^{+}$were completely $(n=7)$ and reversibly $(n=3)$ blocked by $10 \mu \mathrm{M} \mathrm{NBQX}$, assuring that all events were mediated by AMPA receptors, as in control conditions. In $40 \mathrm{~mm} \mathrm{~K}^{+}$, the peak of the pooled amplitude distribution doubled ( $48.5 \mathrm{pA}, n=2902$ EPSCs, 8 calyx recordings, Fig. $2 H$, red) compared with $5.8 \mathrm{~mm} \mathrm{~K}^{+}(20.2 \mathrm{pA}, n=843$ EPSCs, 8 calyx recordings; Fig. $2 \mathrm{H}$, blue). The distribution also widened, exhibiting a longer "tail." For the population of recorded afferents, the average cumulative fraction plot showed a significant rightward shift (Fig. 2I, blue and red bold traces), with mean amplitudes increasing from $63.3 \pm 1.6 \mathrm{pA}$ to $101.3 \pm 1.0 \mathrm{pA}(t$ test, $p<0.0001)$ and the median amplitude increasing from 48.5 to $88.9 \mathrm{pA}$. This observed increase in EPSC amplitudes with hair 
Table 1. EPSC kinetics before and after NMDA receptor blocker (20 $\mu \mathrm{M}$ CPP) application in four calyces

\begin{tabular}{llrlcl}
\hline & Condition & $V_{\mathrm{h}}=-80 \mathrm{mV}^{a}$ & $p$ value & $V_{\mathrm{h}}=60 \mathrm{mV}^{b}$ & $p$ value \\
\hline$\tau_{1}$ (ms) & Control & $2.1 \pm 0.16$ & 0.3 & $4.97 \pm 0.69$ & 0.96 \\
& CPP & $2.5 \pm 0.71$ & & $4.93 \pm 0.99$ & \\
$\tau_{2}(\mathrm{~ms})$ & Control & $10.76 \pm 1.83$ & 0.73 & $12.77 \pm 2.3$ & 0.83 \\
& CPP & $10.14 \pm 0.86$ & & $13.03 \pm 2.5$ & \\
$A_{2} /\left(A_{1}+A_{2}\right)$ & Control & $0.69 \pm 0.09$ & 0.09 & $0.71 \pm 0.1$ & 0.22 \\
& CPP & $0.54 \pm 0.1$ & & $0.66 \pm 0.08$ & \\
& &
\end{tabular}

$p$ values for paired $t$ test. $A_{2} /\left(A_{1}+A_{2}\right)$ shows relative contributions of $\tau_{1 \text { decay }}$ and $\tau_{2 \text { decay }}$ (see Materials and Methods).

${ }^{a}$ Control: $n=984$ EPSCs; CPP: $n=1039$ EPSCS.

${ }^{b}$ Control: $n=356$ EPSCs; CPP: $n=410$ EPSCS.

cell depolarization could be due to increased multivesicular release and could have important functional consequences as larger EPSC amplitudes may result in larger EPSPs, increasing the likelihood of AP generation in the calyx.

\section{AMPA-mediated EPSCs in calyx afferent fibers have mixed fast and slow kinetics}

In afferents with either single or complex calyx terminals, EPSCs showed a wide range of waveforms in $5.8 \mathrm{mM} \mathrm{K}^{+}$, with the hair cell at rest. Figure $3 A$ shows three example EPSCs: EPSCs in Figure $3 A 1$ and $A 2$ are best fit with a single exponential, Figure $3 A 1$ showing a faster event with a time constant of decay $\left(\tau_{\text {decay }}\right)$ of $0.54 \mathrm{~ms}$, and Figure $3 A 2$ showing a slower event with a $\tau_{\text {decay }}$ of $\sim 6 \mathrm{~ms}$. Figure $3 A 3$ shows an EPSC with both faster and slower components, best fit with two exponentials with a $\tau_{1}$ of $0.6 \mathrm{~ms}$ and $\tau_{2}$ of $3.5 \mathrm{~ms}$. Summated events made up $<10 \%$ of all EPSCs and were excluded from waveform analysis (data not shown). For the population of 46 recorded calyces, $\tau_{1}$ was $2.7 \pm 0.4 \mathrm{~ms}$ (range: $0.6-11.5 \mathrm{~ms}$ for individual recordings) and $\tau_{2}$ was $16.1 \pm 1.9 \mathrm{~ms}$ (range: $4.3-101.7 \mathrm{~ms}$ ). The contribution of the slow component to the total amplitude, measured as $A_{2} /\left(A_{1}+\right.$ $A_{2}$ ), was on average $48.5 \pm 0.02 \%$ (range: $13.4-71.2 \%$ ), indicating large variability between recordings regarding the contribution of faster and slower components. Half of the recordings had average EPSCs with decay times best fit by two exponentials ( 23 of 46 cells), whereas the other half had decay times best fit with one exponential. Forty-four percent of this latter group ( 10 of 23 cells) had slow average $\tau_{\text {decays }}>10 \mathrm{~ms}$. Thus, in a large percentage of recordings (72\%), a slow process was involved in the generation of EPSCs, either alone or in combination with a faster process. In summary, EPSC waveforms were variable within and between recordings and best fit with either one or two exponentials. Therefore, as both fitting methods included some level of inaccuracy and depending on the goal of the analysis, either method was applied.

To provide an overview over the range of waveform kinetics within and between recordings, distributions of $\tau_{\text {decays }}$ were assembled based on single exponential fits of EPSC decay times. The distribution of $\tau_{\text {decays }}$ for a single recording is shown in Figure $3 B$, with a peak $<5 \mathrm{~ms}$ and a long tail reaching values up to $120 \mathrm{~ms}$. For this recording, the mean $\tau_{\text {decay }}$ was $13.4 \pm 1.8 \mathrm{~ms}$ and the median was $6.8 \mathrm{~ms}(n=126$ EPSCs for one example calyx recording). Similarly, for the population of recorded calyces, the distribution of $\tau_{\text {decays }}$ had a peak $<5 \mathrm{~ms}$ and showed a long tail toward larger values, with mean and median values of $18.7 \pm 2.8$ $\mathrm{ms}$ and $3.4 \mathrm{~ms}$ ( $n=4633$ EPSCs, 46 calyx recordings; Fig. $3 C)$. The slowest $\tau_{\text {decays }}$ reached values of $>500 \mathrm{~ms}$ (Fig. $3 C$, inset), leading to unusually slow EPSCs. Faster EPSCs $\left(\tau_{\text {decay }}<10 \mathrm{~ms}\right)$ spanned over the entire range of EPSC amplitudes, whereas most of the slower events $\left(\tau_{\text {decay }}>10 \mathrm{~ms}\right)$ had smaller amplitudes $(<50$ pA; Fig. 3D, gray shaded area).
To test whether EPSCs with unusually slow $\tau_{\text {decays }}$ also appear at body temperature, EPSC waveforms were measured at both room temperature and body temperature in individual calyx recordings $\left(25-27^{\circ} \mathrm{C}\right.$ vs $\left.35-37^{\circ} \mathrm{C}\right)$. Pooled distributions of $\tau_{\text {decays }}$ at both temperatures show that unusually slow EPSCs with $\tau_{\text {decays }}$ reaching values up to 273 ms were maintained at body temperature (Fig. 3E). Average decay time constants were not significantly different at both temperatures (mean $\tau_{\text {decays }}$ of $10.7 \pm 5.6$ and $7.4 \pm 2.4$ at $25-27^{\circ} \mathrm{C}$ and $35-37^{\circ} \mathrm{C}$, respectively, $n=6$ calyx recordings, paired $t$ test, $p=0.3$ ). Similarly, analysis of the EPSCs using double exponential fits did not show any significant difference in the average $\tau_{\text {decays }}\left(25-27^{\circ} \mathrm{C}: \tau_{\text {fast }}=4.3 \pm 0.9 \mathrm{~ms}, \tau_{\text {slow }}=\right.$ $25.2 \pm 5.3 \mathrm{~ms} ; 35-37^{\circ} \mathrm{C}: \tau_{\text {fast }}=4.5 \pm 1.0 \mathrm{~ms}, \tau_{\text {slow }}=16.2 \pm 2.5$ ms; $n=6$; paired $t$ test, $p>0.7$ for both conditions). The only difference between the two temperatures was observed for EPSCs with $\tau_{\text {decays }}<10 \mathrm{~ms}$. For these faster EPSCs, the mean $\tau_{\text {decay }}$ decreased at body temperature compared with room temperature (mean $\tau_{\text {decay }}$ of $3.4 \pm 0.1 \mathrm{~ms}$ and $3.0 \pm 0.1 \mathrm{~ms}$ at $25-27^{\circ} \mathrm{C}$ and $35-37^{\circ} \mathrm{C}$, respectively, 6 calyx recordings, paired $t$ test, $p<$ $0.001)$. Cumulative plots of the $\tau_{\text {decays }}$ for 46 individual recordings again illustrate the wide range of distributions between recordings at room temperature (Fig. $3 F$ ). For the average cumulative fraction plot (black line), $\sim 75 \%$ of events had a $\tau_{\text {decay }}$ $<10 \mathrm{~ms}$ and $25 \%$ of EPSCs showed larger $\tau_{\text {decays. }}$. Cumulative fraction plots of $\tau_{\text {decay }}$ of 10 recordings at body temperature (red lines) show that their values lie within the range of recordings performed at room temperature. In summary, these findings suggest that although temperature does affect faster $\tau_{\text {decays }}$, the underlying process responsible for the unusually slow $\tau_{\text {decays }}$ is still functional at body temperature. As such, the remaining data presented in this paper were collected at room temperature.

\section{Glutamate spillover contributes to the slow kinetics of EPSCs at the type I hair cell/calyx synapse}

One explanation for the occurrence of small and slow EPSCs is that glutamate spillover to glutamate receptors located further away from the release site occurs, as observed in other systems (DiGregorio et al., 2007). The presence of such a phenomenon at the calyx afferent seems likely because of the closed synaptic space. To test whether the slow kinetics of EPSCs could be due to glutamate spillover, three experimental approaches were used. As a first approach to induce accumulation of glutamate in the synaptic cleft the probability of glutamate release was increased by depolarizing the hair cell by raising the external $\left[\mathrm{K}^{+}\right]$from 5.8 to $40 \mathrm{~mm}$. The expectation was that increased glutamate accumulation and possible spillover would cause an increase in $\tau_{\text {decay }}$. Figure $4 A 1$ shows the normalized average EPSC in $5.8 \mathrm{~mm} \mathrm{~K}^{+}$ (black) versus $40 \mathrm{~mm} \mathrm{~K}^{+}$(gray) in an example calyx recording. As expected, the average $\tau_{\text {decay }}$ increased from $2.3 \pm 0.17 \mathrm{~ms}$ in 5.8 $\mathrm{mM} \mathrm{K}^{+}(n=125$ EPSCs $)$ to $11.6 \pm 0.75 \mathrm{~ms}$ in $40 \mathrm{mM} \mathrm{K}^{+}(n=777$ EPSCs; $t$ test, $p<0.0001)$. From this example recording, the distribution of $\tau_{\text {decays }}$ shows an increase in the number of slower decay time constants in $40 \mathrm{mM} \mathrm{K}^{+}$(Fig. 4A2). Figure $4 A 3$ compares EPSC decay times for 17 recordings in 5.8 and $40 \mathrm{~mm}$ external $\mathrm{K}^{+}$, with increased $\tau_{\text {decays }}$ plotted above the unity line. In 9 of 17 calyces with average EPSC decay time constants of $<10 \mathrm{~ms}$ in $5.8 \mathrm{mM} \mathrm{K}^{+}, \tau_{\text {decay }}$ increased in $40 \mathrm{mM} \mathrm{K}^{+}$, whereas eight recordings did not show a significant change. When all 17 recordings were considered together, the average $\tau_{\text {decay }}$ showed a significant increase of $\sim 70 \%$, from $4.9 \pm$ $0.6 \mathrm{~ms}$ in $5.8 \mathrm{mM} \mathrm{K}^{+}$to $8.5 \pm 1.7 \mathrm{~ms}$ in $40 \mathrm{mM} \mathrm{K}^{+}(n=17$, paired $t$ test, $p=0.03$; Fig. $4 F$ ).

In a second set of experiments, glutamate accumulation was increased by application of the general glutamate transporter 
A1

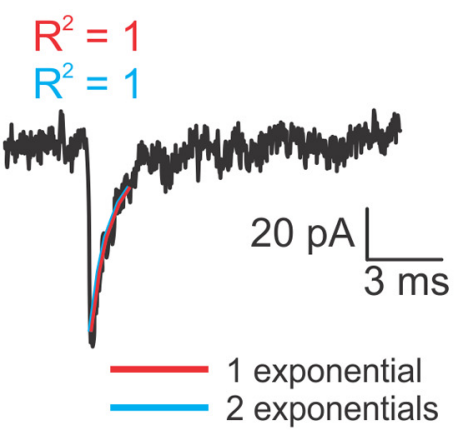

A2

$$
\begin{aligned}
& R^{2}=0.97 \\
& R^{2}=0.96
\end{aligned}
$$

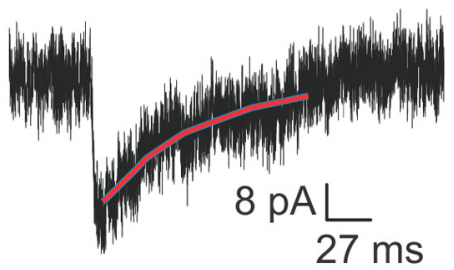

A3

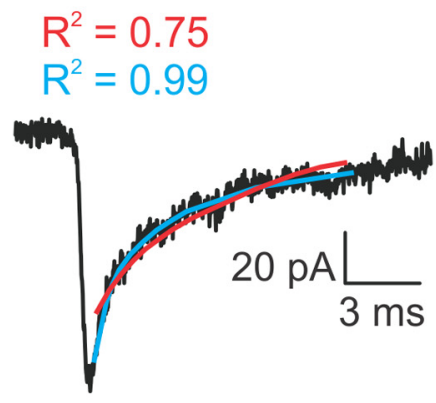

E

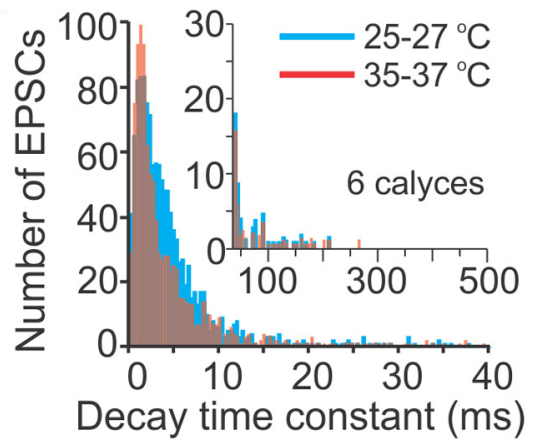

B

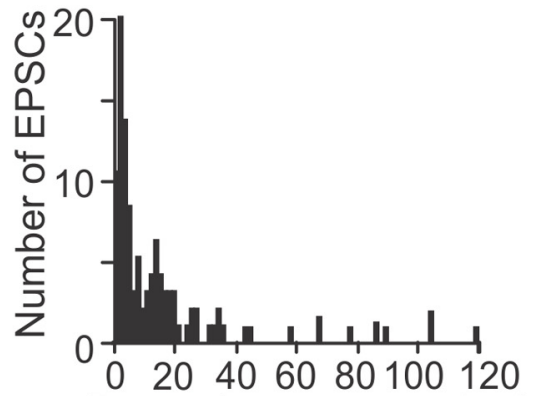

C

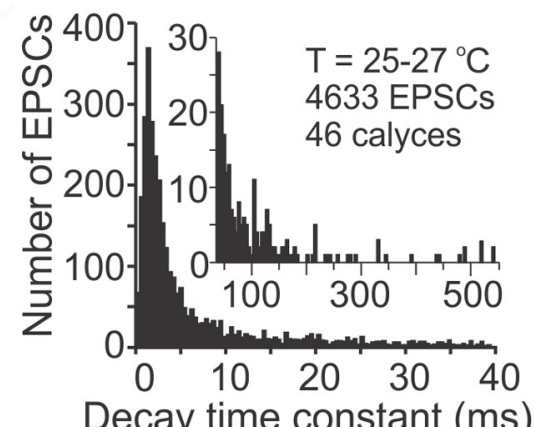

D

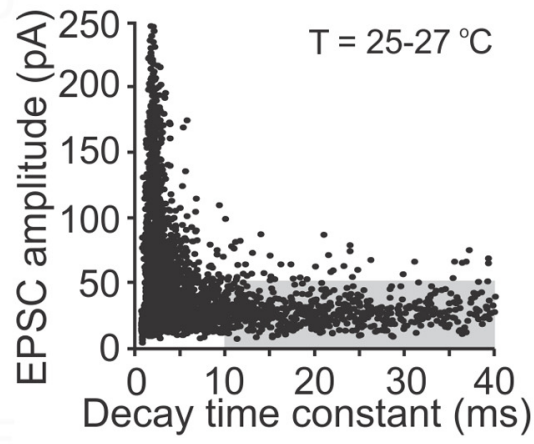

$\mathbf{F}$

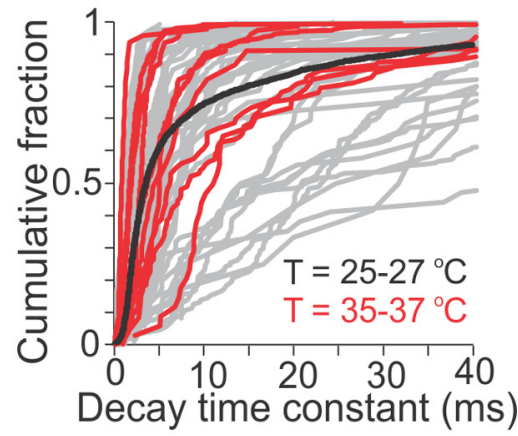

the calyx (data not shown). This inward current was present in all conditions and did not affect the shape of the EPSCs. During application of $200 \mu \mathrm{M}$ TBOA, the average EPSC slowed down reversibly (Fig. $4 B 1)$ and the distribution of $\tau_{\text {decays }}$ showed an increase in slower events (Fig. $4 B 2$ ). For the example recording shown, the average $\tau_{\text {decay }}$ increased during TBOA application from $5.7 \pm 1.2 \mathrm{~ms}(n=105$ EPSCs) to $10.1 \pm 1.7 \mathrm{~ms}$ ( $n=111$ EPSCs) and decreased after washout to $6.7 \pm 0.9$ ms $(n=102$ EPSCs; one-way ANOVA with post hoc Tukey test, $p<0.03$ for TBOA compared with control and washout; Fig. 4B2, inset). For the population of recorded calyces, the average $\tau_{\text {decay }}$ increased by $\sim 40 \%$ from $4.7 \pm 0.6 \mathrm{~ms}$ to $6.6 \pm 1.0 \mathrm{~ms}(n=11$, paired $t$ test, $p=$ 0.007; Fig. $4 F)$.

Finally, a competitive blocker of glutamate receptors, kynurenic acid (KynA), was used to block the receptors that were reached by a lower glutamate concentration, thereby blocking the effect of spillover (Cadetti et al., 2008). Again, ATP was applied at all times to raise the baseline release rate of glutamate. During application of $250 \mu \mathrm{M}$ KynA the average EPSC showed faster $\tau_{\text {decays }}$ (Fig. 4C1) and the distribution of $\tau_{\text {decays }}$ showed fewer slower events (Fig. 4C2) compared with control. For the example recording shown, the average $\tau_{\text {decay }}$ decreased from $9.8 \pm 0.9 \mathrm{~ms}$ $(n=390$ EPSC) to $6.3 \pm 0.7 \mathrm{~ms}(n=164$ EPSC) and returned to control values after washout $(8.9 \pm 0.7 \mathrm{~ms}, n=201 \mathrm{EPSCs}$; one-way ANOVA with post hoc Tukey test, $p<0.004$ for KynA compared with control and washout; Fig. 4C2, inset). For the population of recorded calyces, the average $\tau_{\text {decay }}$ of EPSCs decreased by $\sim 40 \%$ from $5.9 \pm 0.9 \mathrm{~ms}$ to $3.6 \pm 0.7 \mathrm{~ms}$ in KynA $(n=8$, paired $t$ test, $p=0.0001$; Fig. $4 F)$.

Direct comparison of normalized average EPSCs recorded from the same calyx during TBOA or KynA application showed that $\tau_{\text {decay }}$ of the average EPSC during TBOA application could be best fit by two exponentials $\left(\tau_{\text {decays }}\right.$ of $1.4 \mathrm{~ms}$ and $11.9 \mathrm{~ms}, R^{2}=0.99$ vs 0.90 , for a single exponential fit), whereas $\tau_{\text {decay }}$ of the average EPSC during KynA application could be best fit by a single exponential ( $\tau_{\text {decay }}$ of $2.5 \mathrm{~ms}, R^{2}=0.99$ for both fits; Fig. $4 D)$. When plotting $\tau_{\text {decay }}$ with drug versus $\tau_{\text {decay }}$ in control for all experiments, results recorded in TBOA and KynA were Figure 3. EPSC time course of decay shows fast and also unusually slow components. $A$, Example EPSCs from an individual calyx recording at room temperature show a faster EPSC $(\boldsymbol{A} \mathbf{1})$ and a slower EPSC $(\boldsymbol{A} \mathbf{2})$, both with decay times best fit with a single exponential and an EPSC with a decay time best fit with two exponentials (A3). $\boldsymbol{B}$, The distribution of $\tau_{\text {decays }}$ (single exponential fit) for the calyx recording in $\boldsymbol{A}$ exhibits a tail with unusually slow $\tau_{\text {decays }}>10 \mathrm{~ms}$. C, Distribution of $\tau_{\text {decays }}$ for pooled EPSCs from 46 calyx recordings at room temperature shows a tail with unusually slow $\tau_{\text {decays }}>10 \mathrm{~ms}$. Inset, Distribution for values $>40 \mathrm{~ms}$. $D$, EPSC amplitudes as a function of $\tau_{\text {decay }}$ for individual EPSCs recorded from 46 calyces at room temperature. The gray box marks EPSCs that were considered small $(<50 \mathrm{pA})$ and slow $\left(\tau_{\text {decay }}>10 \mathrm{~ms}\right)$. E, Comparison of EPSC $\tau_{\text {decays }}$ recorded at room and body temperature. Distributions pooled from six recordings. At body temperature, slow events persist. $\boldsymbol{F}$, Cumulative fraction plots of $\tau_{\text {decays }}$ for individual calyces recorded at room temperature (gray) and their average (black), and at body temperature (red).

blocker TBOA to block uptake of synaptic glutamate. To raise the baseline release rate, ATP was applied during control conditions, drug application, and washout. ATP activates $\mathrm{P} 2 \mathrm{X}$ receptors on type I hair cells and has a depolarizing effect (Rennie and Ashmore, 1993). In addition, ATP also induced an inward current in separated by the unity line (Fig. $4 E$ ).

When the analysis for all three experimental approaches (application of elevated $\left[\mathrm{K}^{+}\right]$, TBOA, or KynA) was repeated with fitting EPSC decay times with two exponentials, results were consistent with the single exponential analysis. Interestingly, com- 
A1

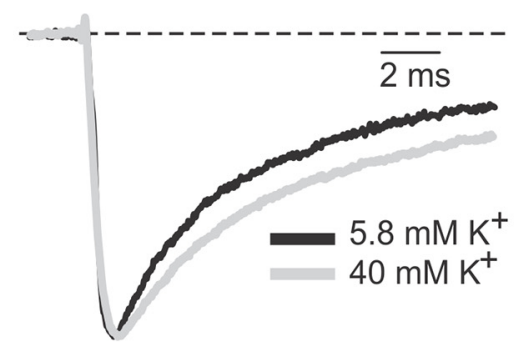

B1

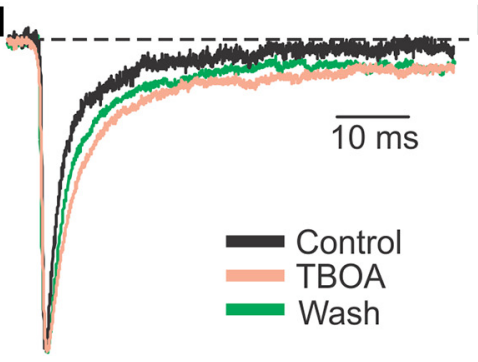

C1

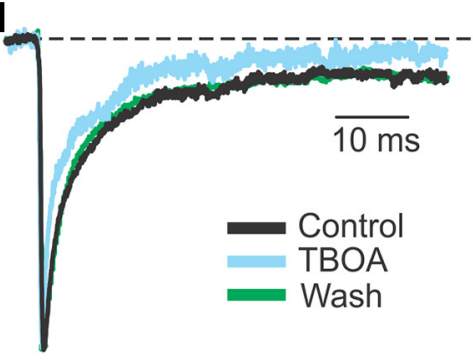

F

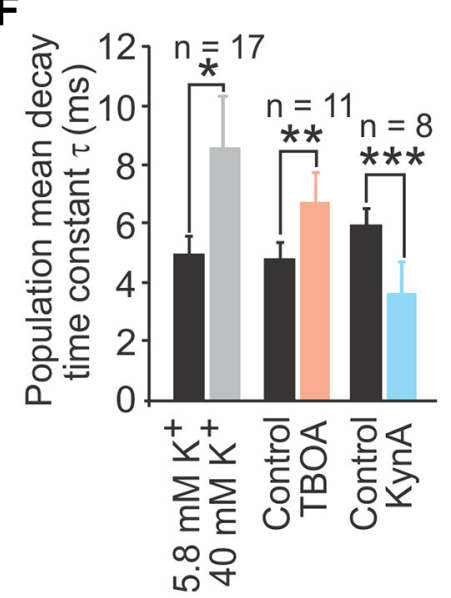

A2

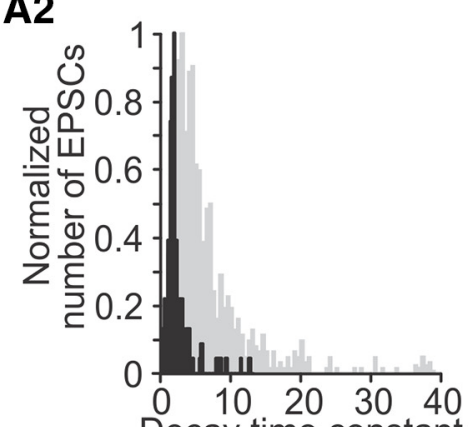

B2

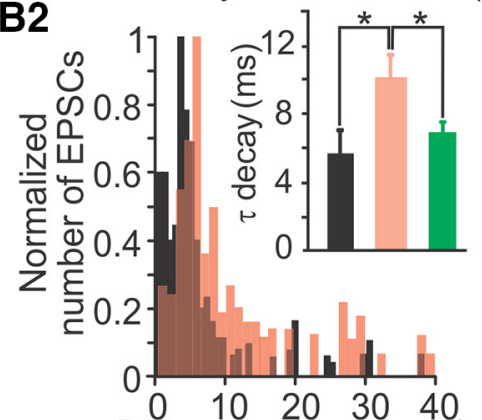

A3

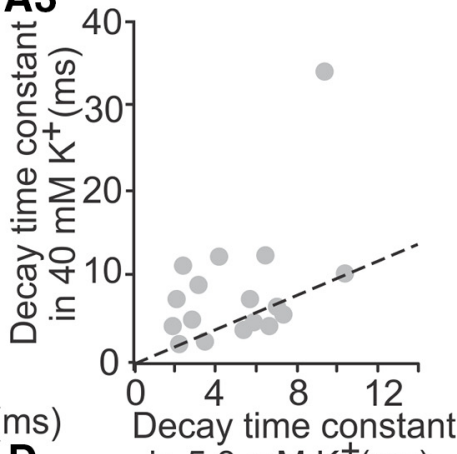

C2

Decay time constant (ms)
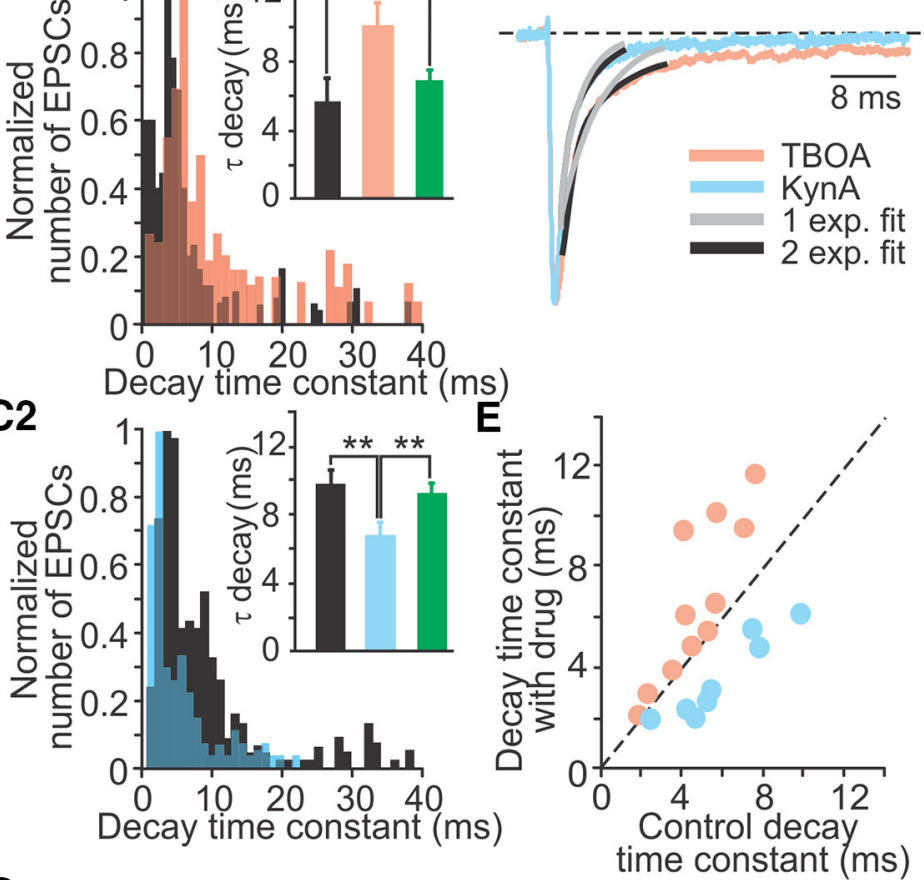

G
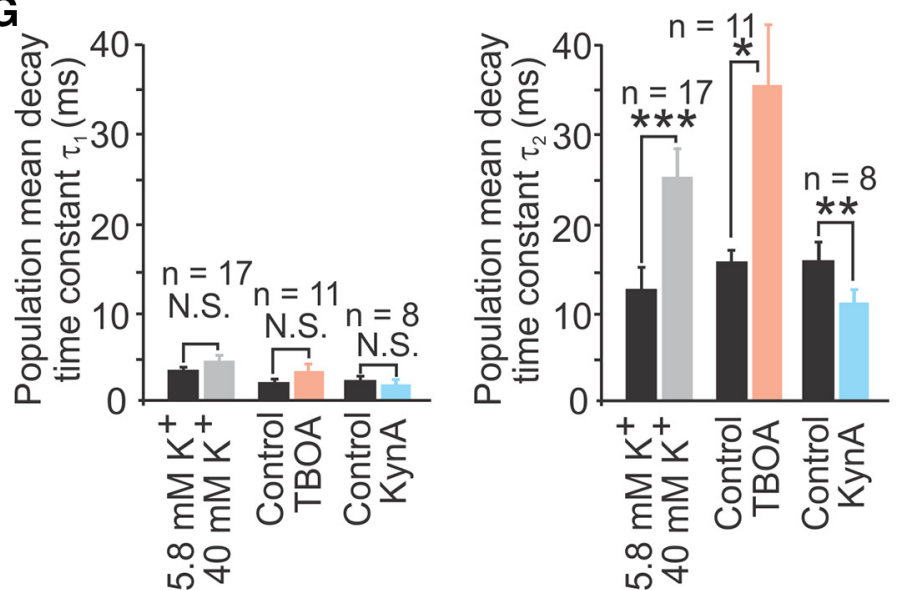

Figure 4. Glutamate accumulation and spillover contribute to slowing of EPSCS in calyx afferents. $A$, During application of $40 \mathrm{~mm} \mathrm{~K}^{+}$, the normalized average EPSC from an example calyx recording showed slower kinetics $(\boldsymbol{A} \mathbf{1})$ with an increase in $\tau_{\text {decay }}(\boldsymbol{A} \mathbf{2})$. Nine of 17 calyces showed an increase in $\tau_{\text {decay }}(\boldsymbol{A 3})$. The dashed line represents the unity line. $\boldsymbol{B}$, In $200 \mu \mathrm{M}$ TBOA, the normalized average EPSC from an example calyx recording slowed down reversibly $(\boldsymbol{B} \mathbf{1})$ and the distribution of $\tau_{\text {decays }}$ (B2) showed an increase in larger $\tau_{\text {decays }}$, resulting in a significant increase in the mean $\tau_{\text {decay }}$ (B2, inset). $\boldsymbol{C}, \ln 250 \mu \mathrm{M}$ KynA, the normalized average EPSC from an example calyx recording became reversibly faster (C1) and the distribution of $\tau_{\text {decays }}(\mathbf{C} 2)$ showed an increase in smaller $\tau_{\text {decays }}$ resulting in a decrease in the mean $\tau_{\text {decay }}(\mathbf{C}$, inset). $\boldsymbol{D}$, An example recording showing a faster one exponential decay for the average EPSC during KynA application compared with a two exponential decay during TBOA application. $\boldsymbol{E}$, Changes in $\tau_{\text {decay }}$ during TBOA or KynA application. $\boldsymbol{F}$, Single exponential fits and $(\boldsymbol{G})$ double-exponential fits of $\tau_{\text {decays }}$ for the population of recorded calyces show significant changes for all conditions applied. $n$, Number of recordings per condition; ${ }^{*} p<0.05$, ${ }^{* *} p<0.01$, ${ }^{* * *} p=0.0001$. 
Table 2. EPSC kinetics before and during application of extracellular solution with $40 \mathrm{mM} \mathrm{K}^{+}$( $n=17$ recordings), $200 \mu \mathrm{M} \mathrm{TBOA} \mathrm{(} n=11$ recordings), or $250 \mu \mathrm{M}$ KynA ( $n=8$ recordings)

\begin{tabular}{lcclcclccc}
\hline & Control & High $\left[\mathrm{K}^{+}\right]$ & $p$ value & Control & TBOA & $p$ value & Control & KynA & $p$ value \\
\hline$\tau_{1}$ & $3.2 \pm 0.4$ & $4.2 \pm 0.6$ & 0.08 & $1.9 \pm 0.4$ & $3.2 \pm 0.8$ & 0.07 & $2.2 \pm 0.4$ & $1.8 \pm 0.4$ & 0.15 \\
$\tau_{2}$ & $12.2 \pm 2.5$ & $24.6 \pm 3.2$ & $0.0007^{*}$ & $15.3 \pm 1.4$ & $34.9 \pm 6.7$ & $0.02^{*}$ & $15.5 \pm 1.8$ & $10.9 \pm 1.7$ & $0.006^{*}$ \\
$A_{2} /\left(A_{1}+A_{2}\right)$ & $0.4 \pm 0.06$ & $0.4 \pm 0.05$ & 0.4 & $0.4 \pm 0.05$ & $0.4 \pm 0.04$ & 0.4 & $0.5 \pm 0.06$ & $0.4 \pm 0.05$ & 0.08 \\
\hline
\end{tabular}

*Significant $p$ values for paired $t$ test.

$A_{2} /\left(A_{1}+A_{2}\right)$ shows relative contributions of $\tau_{1 \text { decay }}$ and $\tau_{2 \text { decay }}$ (see Materials and Methods).

pared with controls, significant changes were not found for $\tau_{1 \text { decay, }}$ but for $\tau_{2 \text { decay }} \cdot \tau_{1 \text { decay }}$ stayed at $2-4 \mathrm{~ms}$ for all controls and drugs tested. However, $\tau_{2 \text { decay }}$ at $12-16 \mathrm{~ms}$ in control, increased in elevated $\left[\mathrm{K}^{+}\right]$and in TBOA by $100-130 \%$ and decreased in KynA by $\sim 30 \%$ (Fig. $4 G$; Table 2).

During the experiments with elevated $\left[\mathrm{K}^{+}\right]$or TBOA, one factor that could have shaped the EPSC waveform is enhanced glutamate receptor desensitization due to glutamate accumulation (Trussell et al., 1993). Individual EPSCs in calyx afferents were affected by desensitization: in $5.8 \mathrm{mM} \mathrm{K}^{+}$external solution, both $\tau_{1 \text { decay }}$ and $\tau_{2 \text { decay }}$ increased approximately three times in $100 \mu \mathrm{M}$ cyclothiazide (CTZ), a drug that removes desensitization from AMPA receptors [Yamada and Rothman, 1992; control vs CTZ $(n=26$ vs 47 EPSCs $): \tau_{1}=1.34 \pm 0.14$ vs $4.28 \pm 0.37 \mathrm{~ms}(t$ test, $p<0.0001)$ and $\tau_{2}=9.32 \pm 2.03$ vs $33.42 \pm 4.81 \mathrm{~ms}(p=$ $0.0005)]$. However, in elevated $\left[\mathrm{K}^{+}\right]$or TBOA, no effect was found for $\tau_{1 \text { decay, }}$ and a change in $\tau_{1 \text { decay }}$ would have been expected if desensitization had caused EPSC waveform changes in these conditions. Together with the most direct evidence, a decreased $\tau_{2 \text { decay }}$ in KynA, the most likely explanation for the results of all three experimental approaches is that glutamate accumulation and spillover occurred to shape EPSCs with slow-waveform components.

\section{Not all glutamate receptor patches in the calyx are juxtaposed to presynaptic ribbons}

To investigate whether the relative location of presynaptic release sites (hair cell ribbons) and postsynaptic AMPA receptor patches (on afferent calyces) somehow favors the occurrence of spillover, vestibular cristae from rats aged P17-P21 were isolated and labeled with antibodies against CTBP2 (a marker of presynaptic ribbons) and glutamate receptor subtypes GluA2/3 (a marker of postsynaptic AMPA receptors). Additionally, an antibody against Tubulin J (TuJ) was used to label the cytoplasm of afferent fibers and terminals to identify calyces by their typical shapes. Figure $5 \mathrm{~A}$ shows a single optical section of four hair cells from the central zone of an anterior crista. Figure $5 A$, inset 1 shows immunolabeled puncta, CTBP2 (green), and GluA2/3 (red), at the inner face of a TuJ labeled calyx (blue). Between calyces, a type II hair cell can be identified by the presence of its nucleus without a surrounding calyx label and with CTBP2 and GluA2/3 immunolabeled puncta at its base, marking its bouton-type ribbon synapses (Fig. 5A, inset 2). For the present study, only the labels at the type I hair cell/calyx synapse, at the inner face of the TuJ labeled calyx, were quantified.

To quantitatively assess the relative position of presynaptic ribbons and postsynaptic AMPA receptor patches in type I hair cell/calyx synapses, first the total number and spatial locations of CTBP2 and GluA2/3 immunolabels were determined from 3D reconstructions from stacks of confocal micrographs from 17 counts of single or complex calyces (2-3 calyces each) located in the central zones of cristae of nine animals from three litters (4-7 calyces/animal giving a total of 36 calyces). The average number of CTBP2 and GluA2/3 labels counted were not different (38.9 \pm 3.7 and $32.5 \pm 4.2, n=17, t$ test, $p=0.25$ ). The average number of CTBP2 labels per hair cell was calculated as $19.0 \pm 1.3$ and that of GluA2/3 labels per calyx was calculated as $15.5 \pm 1.5$. Inspection by eye revealed that CTBP 2 and GluA2/3 labels were often not juxtaposed. As shown in Figure $5 A$ and $C$, in some cases single GluA2/3 and CTBP2 immunolabels appeared juxtaposed (arrowhead, magnified inset 4 ), supporting fast activation of glutamate receptors. Sometimes GluA2/3 immunolabels were located in the vicinity of CTBP2 immunolabeled puncta (Figs. $5 \mathrm{~A}, \mathrm{C}$, white arrows, magnified insets 1 and 6), potentially allowing glutamate receptor activation through spillover, with possible direct activation as well. Finally, some GluA2/3 immunolabels appeared alone with no closely related CTBP 2 immunolabels or vice versa (blue arrows, magnified insets 1, 4, 5, and 6).

To quantify the juxtaposition of presynaptic and postsynaptic immunolabels objectively, the distance between the centers of immunolabels was calculated. These values were compared with equivalent measurements from immunolabeled cochlear inner hair cell (IHC) afferent synapses (Fig. 5B, inset 3), where CTBP2 and GluA2/3 immunolabels are known to be juxtaposed in a near 1:1 relationship (Khimich et al., 2005; Liberman et al., 2011), as it was also observed in the experiments presented here. Figure $5 D$ (red) shows that in the IHC area $\sim 90 \%$ of CTBP2 patches were $<1 \mu \mathrm{m}$ away from a GluA2/3 patch and vice versa. In contrast, $<50 \%$ of GluA2/3 immunolabels were within $1 \mu \mathrm{m}$ of a CTBP2 immunolabel and vice versa in the vestibular crista (Fig, $5 D$, blue). Note, that in control experiments in both vestibular crista and the organ of Corti $\sim 90 \%$ of GluA2/3 antibodies were colocalized with PSD95 immunolabels (data not shown), a structural protein found in glutamatergic postsynaptic densities in general (Kennedy, 1997; Béïque et al., 2006), suggesting that GluA2/3 detects most glutamatergic postsynaptic densities in calyx afferents. The calculated distances between CTBP2 and GluA2/3 immunolabels do not necessarily reflect absolute distances between presynaptic ribbons and postsynaptic AMPA receptor patches (with deviations likely resulting from the inherent limits of resolution imposed by immunofluorescence and confocal microscopy).

In summary, the complex spatial relationship between presynaptic and postsynaptic immunolabels in the vestibular crista compared with the cochlea can explain the variable shapes of EPSCs with fast and/or slow components of decay. The histological data are consistent with the hypothesis that glutamate spillover plays an important role in activating EPSCs. The large variability in the relative localization of presynaptic and postsynaptic sites, within and between calyces, may account for the variability of EPSC waveforms within and between recordings.

\section{Glutamate accumulation and spillover increases the firing rate of calyx afferents}

To study the functional implications of glutamate accumulation and spillover at the type I hair cell/calyx synapse, calyx AP firing rates and membrane potentials were examined in current-clamp. 
A

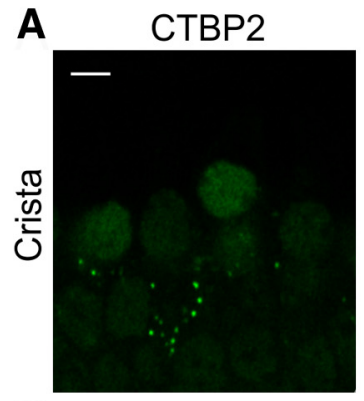

B

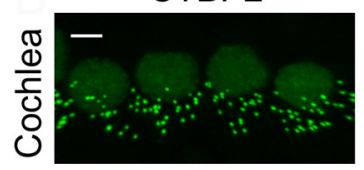

GluA2/3

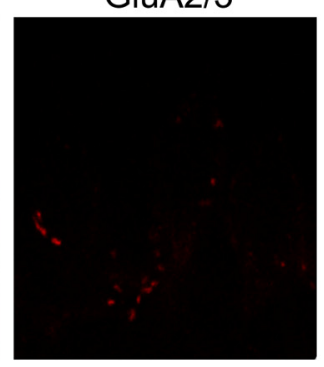

GluA2/3

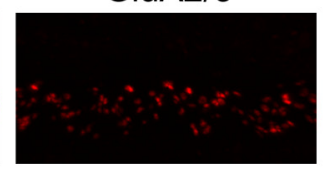

5

c

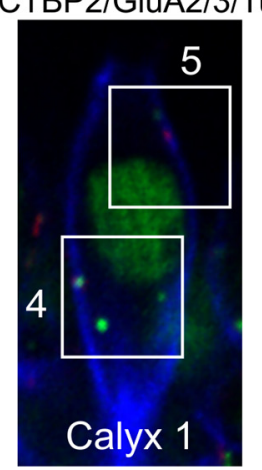

D

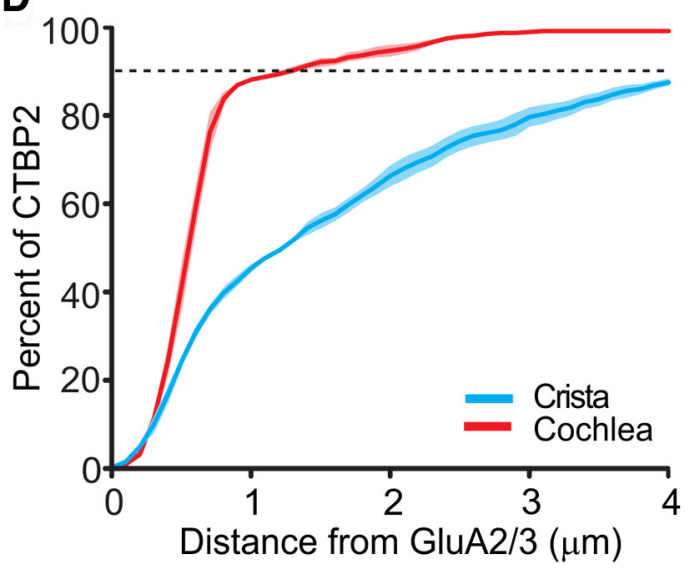

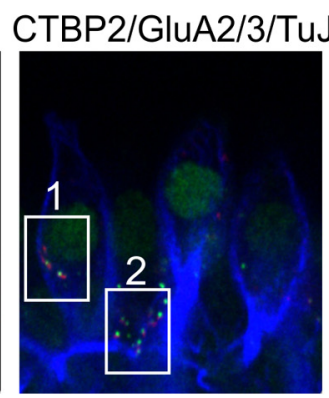

CTBP2/GluA2/3
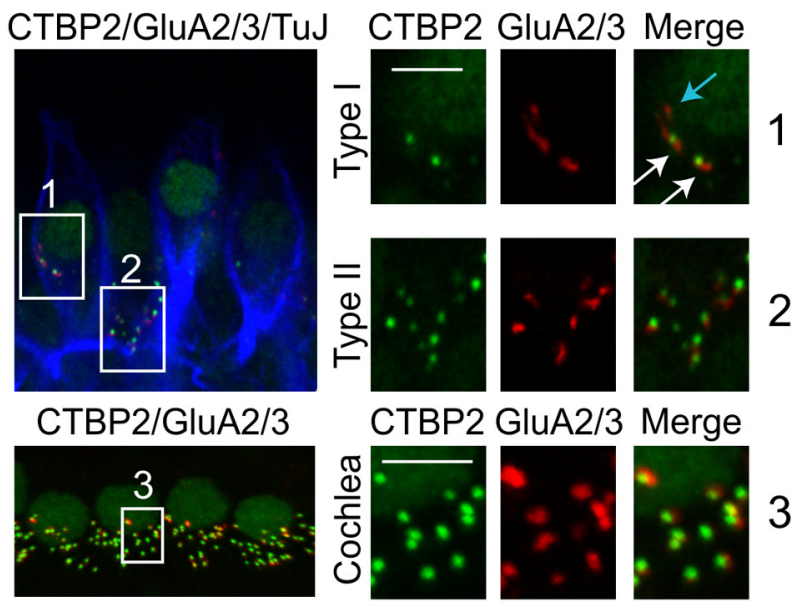

2
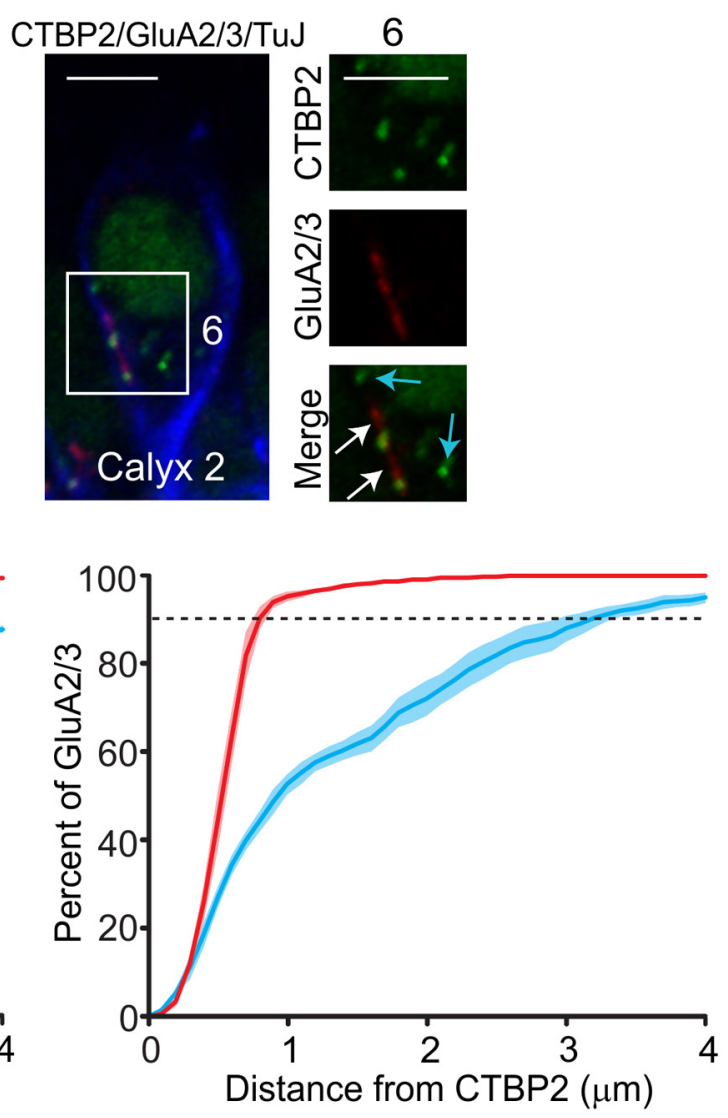

Figure 5. Structural evidence is consistent with glutamate spillover in the synaptic cleft. $\boldsymbol{A}$, High-magnification micrographs of single optical sections from the central region of the horizontal crista show presynaptic ribbons (anti-CTBP2, green) and postsynaptic glutamate receptors (anti-GluA2/3, red) associated with afferent endings (anti-TuJ, blue). Scale bar, $10 \mu \mathrm{m}$. Insets, Type I hair cell/calyx afferent synapses (inset 1) and type II hair cell/bouton afferent synapses (inset 2). White arrows, GluA2/3 close to CTBP2 immunolabeled puncta. Blue arrow, GluA2/3 immunolabels with no closely related CTBP2 immunolabels. Scale bar, $3 \mu \mathrm{m}$. B , High-magnification micrographs of z-projections from the apical turn of the organ of Corti. Scale bar, $10 \mu \mathrm{m}$. Inset 3 shows a close to $1: 1$ relationship between presynaptic and postsynaptic labels. Scale bar, $3 \mu \mathrm{m}$. C, High-magnification micrographs of two example calyces. Some GluA2/3 immunolabels were juxtaposed to CTBP2 immunolabels (inset 4, arrowhead). Sometimes GluA2/3 immunolabels were located in the vicinity of CTBP2 immunolabeled puncta (inset 6, white arrows), whereas other GluA2/3 immunolabels appeared alone with no closely related (TBP2 immunolabels or vice versa (insets 4, 5, and 6, blue arrows). Scale bar, $3 \mu \mathrm{m}$. D, Comparison of the distances between (TBP2 and GluA2/3 immunolabels. Light colors represent SE.

Again, for a higher baseline level of release, $100 \mu \mathrm{M}$ ATP was applied throughout the experiment. Application of $200 \mu \mathrm{M}$ TBOA repeatedly increased the firing rate of afferents from $8.2 \pm$ 5.1 spikes/s to $30.1 \pm 10.3$ spikes/s $(n=5$, paired $t$ test, $p=0.03$; Fig. $6 A$ ). The shape of the average AP in control (black) compared with TBOA (red) was not different (Fig. 6B). However, in TBOA, the membrane potential depolarized gradually over sec- onds by a maximum value of $\sim 5 \mathrm{mV}$, as shown in the example in Figure $6 A$.

To explore this phenomenon in a more controlled fashion, APs were blocked with 1-2 $\mu \mathrm{M}$ TTX. Then, either ATP alone, ATP and TBOA, or ATP and KynA were applied for $\sim 100 \mathrm{~s}$ or until the response reached a plateau. Between drug applications, external solution (no ATP) was applied for washout. These 

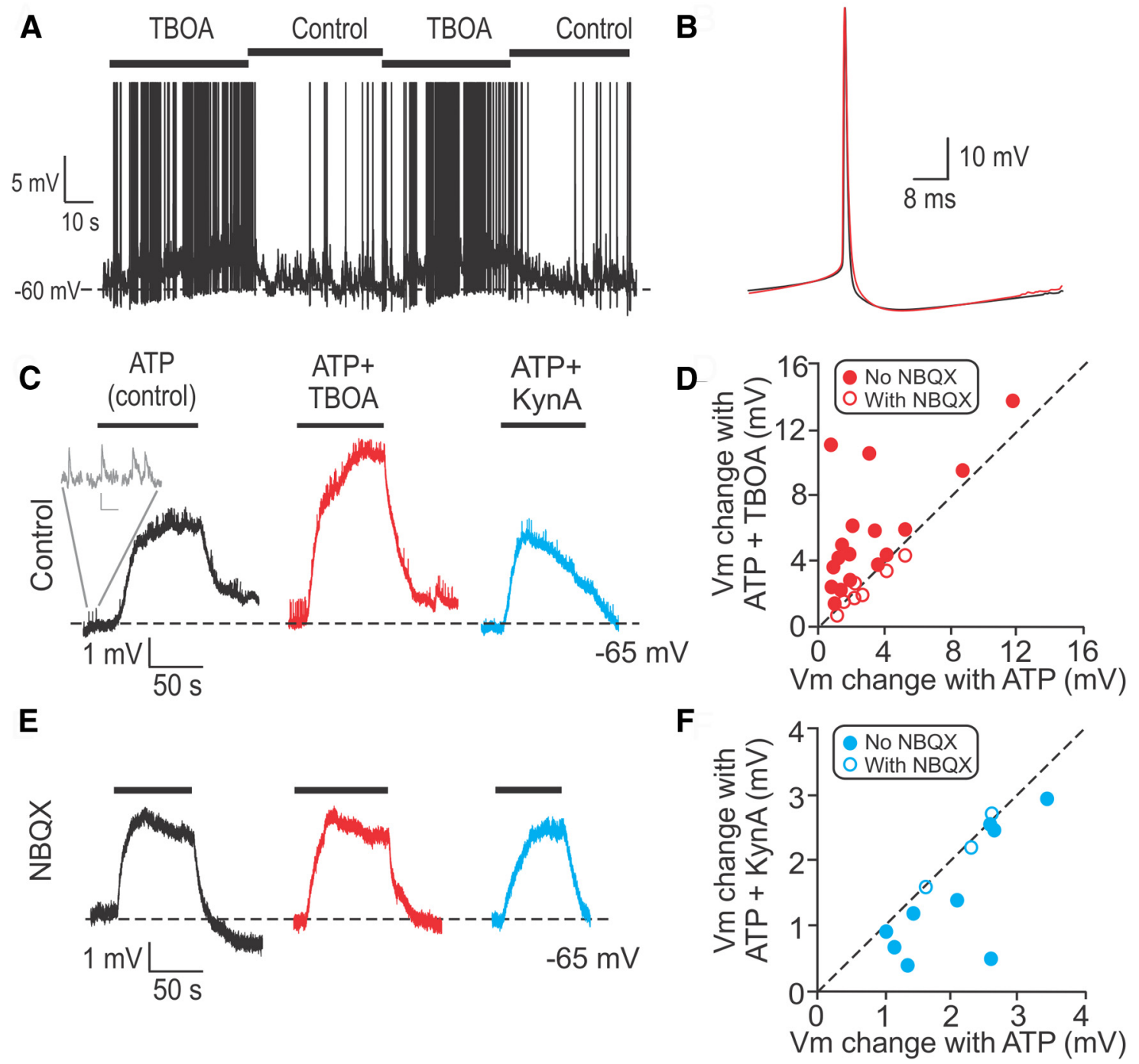

Figure 6. Glutamate accumulation and spillover increase the firing rate of calyces. $A$, In an example calyx recording, during application of $200 \mu \mathrm{M}$ TBOA, the membrane potential depolarized and the firing rate increased from $2.9 \pm 0.7$ spikes/s to $12.1 \pm 7.3$ spikes $/ \mathrm{s}$. In TBOA the membrane potential depolarized by $\sim 5 \mathrm{mV}$. $\boldsymbol{B}$, The AP shape did not change during TBOA application (red). $\boldsymbol{C}$, Comparison of changes in membrane potential during individual ATP applications (to increase release rate from hair cells) without (control) and with TBOA or KynA. Throughout the experiment, 2 $\mu \mathrm{M}$ TTX was applied to block AP generation. Inset (gray), Example EPSPs. Scale bar: $0.2 \mathrm{mV}, 100 \mathrm{~ms}$. In control, ATP causes depolarization mediated by P2X receptors on the calyx membrane. D, Most calyces were further depolarized during TBOA application compared with control (filled symbols above dashed unity line). Empty symbols: TBOA and NBQX application. $E$, During application of 10 $\mu \mathrm{MNBQX}$, the effects of TBOA and KynA shown in C were blocked. Same calyx as in C.F, Most calyces showed less depolarization during KynA application compared with control (filled symbols below dashed unity line). Empty symbols: KynA and NBQX application.

shorter instead of continuous ATP applications were used because prolonged ATP applications resulted in decreased rates of EPSPs. ATP application depolarized calyces due to P2X receptor activation (Fig. $6 C$, black trace). This depolarization served as the control value. Additionally, ATP depolarized the hair cell and increased its rate of release, resulting in higher EPSP rates in the calyx. Calyces showed an increased depolarization during application of TBOA and ATP compared with ATP alone (Fig. 6C). On average, responses increased by $5.0 \pm 0.7 \mathrm{mV}$ (range: $1.5-11.2$ $\mathrm{mV}$ ) compared with the average depolarization of $2.3 \pm 0.6 \mathrm{mV}$ (range: $0.8-8.8 \mathrm{mV}$ ) in ATP alone (paired $t$ test, $p=0.002, n=$ 17; Fig. 6C). All of the 17 calyces tested showed further depolarization during application of TBOA and ATP, placing all data points above the unity line when plotting the change in membrane potential in TBOA and ATP compared with ATP alone (Fig. $6 D$, filled symbols). In contrast, most calyces showed a decreased depolarization during application of KynA and ATP compared with ATP alone (Fig. 6C). On average, responses de- creased from $1.9 \pm 0.3 \mathrm{mV}$ to $0.8 \pm 0.5 \mathrm{mV}$ (paired $t$ test, $p=$ $0.02, n=9$ ), placing most data points below the unity line when plotting the change in membrane potential in KynA and ATP compared with ATP alone (Fig. 6F, filled symbols). Importantly, when these experiments were repeated in the presence of $10 \mu \mathrm{M}$ NBQX (Fig. 6E), depolarizations in ATP alone compared with TBOA and ATP $(2.8 \pm 0.5 \mathrm{mV}$ vs $2.4 \pm 0.5 \mathrm{mV}$, paired $t$ test, $p=$ $0.08, n=7$ ), as well as depolarizations in ATP alone compared with KynA and ATP $(2.2 \pm 0.3$ vs $2.2 \pm 0.4 \mathrm{mV}, n=3$, paired $t$ test, $p=0.8$ ) were not significantly different (Fig. $6 D, F$, open symbols). Together, these results suggest that the changes in membrane depolarization in response to TBOA or KynA application were mediated by AMPA receptors in response to glutamate accumulation and spillover.

\section{Discussion}

The present study characterizes AMPA receptor-mediated synaptic transmission at the highly specialized synapse between the 
vestibular type I hair cell and its afferent calyx ending. Results suggest that glutamate accumulation and spillover in the synaptic cleft lead to a wide range of EPSC kinetics, including unusually slow synaptic events. These effects induce slow depolarizations of the postsynaptic membrane resulting in changes in firing rate.

\section{Comparison of EPSC amplitudes at the vestibular hair cell/ calyx synapse and other ribbon synapses}

Mean EPSC amplitudes of $60-80 \mathrm{pA}$ at a holding potential of $-103 \mathrm{mV}$ were similar to measurements reported previously in the calyx (Rennie and Streeter, 2006; Dulon et al., 2009; Eatock and Songer, 2011), taking into account different recording conditions. EPSC amplitude distributions were well fit by a Gaussian, with a peak at $\sim 20 \mathrm{pA}$, most likely representing the preferred release of individual vesicles, in contrast to the preferred release of multiple vesicles as seen at other hair cell ribbon synapses (Glowatzki and Fuchs, 2002; Goutman and Glowatzki, 2007; Li et al., 2009; Schnee et al., 2013). EPSC amplitudes increased with hair cell depolarization. This phenomenon could be explained by enhanced multivesicular release (Wadiche and Jahr, 2001) similar to changes in EPSC amplitude that occur with depolarization at ribbon synapses in the frog inner ear (Li et al., 2009) and the retina (Singer et al., 2004). Larger EPSC amplitudes may result in larger EPSPs and may increase the likelihood of AP generation in the calyx with hair cell depolarization.

\section{Glutamate accumulation and spillover result in slow EPSC kinetics at the hair cell/calyx synapse}

EPSC waveforms recorded in calyx afferents had an unusually wide range of time courses, with $\tau_{\text {decays }}$ ranging over two orders of magnitude, from $<5$ to $>500 \mathrm{~ms}$, as determined by single exponential fits. For a subset of EPSCs, decay times were best fit with two exponentials, suggesting that more than one mechanism might be at play. When decay times were analyzed with two exponential fits, a faster average $\tau_{1 \text { decay }}$ in the millisecond range and a slower average $\tau_{2 \text { decay }}$ in the tens of millisecond range were found. At body temperature, the slower components of the EPSC waveforms remained, suggesting that this phenomenon also occurs under physiological conditions.

Several lines of evidence support the hypothesis that glutamate accumulation and spillover highly contribute to slowing EPSC kinetics. First, when the glutamate concentration was increased in the synaptic cleft by either increasing the hair cell release rate via increasing external $\left[\mathrm{K}^{+}\right]$or by decreasing glutamate uptake via blocking glutamate transporters with TBOA, the number of slower EPSCs and the average $\tau_{\text {decay }}$ increased. Second, a competitive blocker of glutamate receptors, KynA that blocks receptors activated by spillover, decreased the number of slower events and the average $\tau_{\text {decay. }}$. When the analysis for the experimental approaches with elevated $\left[\mathrm{K}^{+}\right]$, TBOA, or KynA was repeated with two exponential fitting of the EPSC decay times, only the slower $\tau_{2 \text { decay }}$ but not the faster $\tau_{1 \text { decay }}$ was found to be affected. Therefore, it is unlikely that mechanisms like glutamate receptor desensitization (Trussell et al., 1993) or a changed level of multivesicular release (Yamada and Rothman, 1992; Wadiche and Jahr, 2001; Singer et al., 2004) underlie the described changes in elevated $\left[\mathrm{K}^{+}\right]$, TBOA, or KynA, as for these mechanisms a change in the faster $\tau_{\text {1decay }}$ in the millisecond range would have been expected. Third, presynaptic ribbons and postsynaptic glutamate receptor patches were only partially juxtaposed at the type I hair cell/calyx synapse, favoring scenarios where glutamate might reach postsynaptic receptors by spillover.
Previous studies in other brain areas have shown that spillover can activate extrasynaptic NMDA, AMPA, and metabotropic receptors (Kullmann et al., 1996; Barbour and Häusser, 1997; Scanziani et al., 1997; Oliet et al., 2001; Szapiro and Barbour, 2007; Hires et al., 2008) and can play a role as an adjunct to conventional synaptic transmission. However, spillover has also been described as the main mode of synaptic transmission between the climbing fiber and molecular layer interneurons in the cerebellar cortex (Szapiro and Barbour, 2007) and between mitral cells in the olfactory bulb (Isaacson, 1999). Similarly, data presented here suggest a prominent role of spillover at the vestibular hair cell/ calyx synapse during its normal mode of operation, which includes high rates of release, even at rest (Yang and Hullar, 2007; Lasker et al., 2008).

The slow kinetics of EPSCs at the hair cell/calyx synapse with a $\tau_{\text {1decay }}$ of $2-4 \mathrm{~ms}$ and a $\tau_{2 \text { decay }}$ of $12-16 \mathrm{~ms}$ is in strong contrast to the fast kinetics of EPSCs at the IHC afferent synapse in the auditory pathway, with a mean $\tau_{\text {decay }}$ of $0.5 \mathrm{~ms}$ and no second, slower component (Grant et al., 2010). At the IHC afferent synapse, fast events are critical for conserving timing and precision to allow for coding of a wide range of frequencies (up to $111 \mathrm{kHz}$ in bats; Kössl and Vater, 1985) and of small interaural time differences for directional hearing (Carr and Konishi, 1990). For this purpose, an afferent ending receives input from a single ribbon synapse (Liberman, 1980) and individual large multivesicular EPSCs activate individual APs (Yi et al., 2010; Rutherford et al., 2012), avoiding any form of summation. In contrast, the semicircular canals convey head movements $<20 \mathrm{~Hz}$ and the type I hair cell/calyx synapse seems to be designed to rather integrate by receiving inputs from multiple ribbons (Lysakowski and Goldberg, 2008). Due to spillover, slow events, and summation, slow depolarizations occur postsynaptically and this integrated signal changes AP firing rates.

\section{Other possible contributors to EPSC kinetics at the calyx}

Additional mechanisms may contribute to slow depolarizations of the calyx afferent. Several studies have provided evidence for $\mathrm{K}^{+}$accumulation in the synaptic cleft between type I hair cell and calyx (Holt et al., 2007; Lim et al., 2011; Contini et al., 2012). $\mathrm{K}^{+}$ accumulation could induce calyx depolarization via hair cell depolarization and enhanced transmitter release and/or by directly inducing calyx depolarization. Additionally, buildup of $\mathrm{H}^{+}$in the synaptic cleft of the turtle hair cell/calyx synapse has been shown to cause slow changes in postsynaptic currents (Highstein et al., 2014). In the present study, the effects of glutamate accumulation and spillover on the calyx membrane potential, as tested by application of TBOA and $\mathrm{KynA}$, were completely blocked by the AMPA receptor blocker NBQX, suggesting that these effects were mediated by glutamate, but not $\mathrm{K}^{+}$or $\mathrm{H}^{+}$ accumulation. Further investigations are needed to characterize possible relative contributions of glutamate, $\mathrm{K}^{+}$or $\mathrm{H}^{+}$accumulation in signaling at hair cell/calyx synapses in different species and vestibular endorgans.

Experimental conditions for the present study were specifically chosen so that the effects of glutamate accumulation could be measured. The hair cell was depolarized with ATP, for enough glutamate release to occur to induce spillover; on the other hand, release rates had to be kept low enough, so that individual EPSC waveforms were not obscured by summation. With TBOA, glutamate accumulation in the synaptic cleft was enhanced artificially. In vivo, at body temperature, the players involved may work together differently compared with the experiments in vitro. For example, firing rates of afferents in vivo are higher $(\sim 50$ 
spikes/s in mice; Yang and Hullar, 2007; Lasker et al., 2008) compared with in vitro conditions used here ( $\sim 25$ spikes/s). In fact, the high firing rates at rest found in vivo may be partially due to depolarization based on a steady-state current activated by desensitized receptors that are constantly exposed to a low glutamate concentration due to spillover (Trussell et al., 1993; Otis et al., 1996).

\section{Functional significance of glutamate accumulation and spillover at the calyx}

Studies in different species have shown that vestibular afferents with calyx endings show an increase in their sensitivity with increasing frequency over the range of natural stimuli $(<20 \mathrm{~Hz}$; Fernández and Goldberg, 1971; Ramachandran and Lisberger, 2006), and therefore most likely function as "high-frequency" event detectors (Sadeghi et al., 2007). The increase over the low to mid frequency range of stimuli $(<1 \mathrm{~Hz})$ has been explained by the mechanics of the end organ, described by a torsion pendulum model (Fernández and Goldberg, 1971). For higher frequencies, an additional mechanism that acts between hair cell mechanotransduction and the spike generator in the calyx afferent needs to be introduced to explain the measured increase in sensitivity. We propose that such a mechanism may include increased glutamate release at higher frequencies of stimulation resulting in pronounced accumulation and spillover and further increase in firing rate. Indeed, a frequency dependent modulation of spillover has been observed in the hippocampus, where at high-requencies of stimulation, submicromolar glutamate concentrations can persist along the surface of dendrites for hundreds of milliseconds (Hires et al., 2008).

\section{Conclusions}

Our results provide structural and functional evidence that glutamate spillover plays a prominent role in signal transmission at the hair cell/calyx synapse. In other brain areas, this mechanism is used to provide high pass properties (DiGregorio et al., 2002), synchrony (Isaacson, 1999), or gain compression (Oikonomou et al., 2012) of neuronal responses. We propose that spillover in the vestibular periphery may play a role in modifying afferent response sensitivity. Future experiments with better control of hair cell depolarization levels are required to directly evaluate the effect of glutamate accumulation and spillover on the sensitivity of afferents at different amplitudes and frequencies of stimulation.

\section{References}

Barbour B, Häusser M (1997) Intersynaptic diffusion of neurotransmitter. Trends Neurosci 20:377-384. CrossRef Medline

Béïque JC, Lin DT, Kang MG, Aizawa H, Takamiya K, Huganir RL (2006) Synapse-specific regulation of AMPA receptor function by PSD-95. Proc Natl Acad Sci U S A 103:19535-19540. CrossRef Medline

Bonsacquet J, Brugeaud A, Compan V, Desmadryl G, Chabbert C (2006) AMPA type glutamate receptor mediates neurotransmission at turtle vestibular calyx synapse. J Physiol 576:63-71. CrossRef Medline

Cadetti L, Bartoletti TM, Thoreson WB (2008) Quantal mEPSCs and residual glutamate: how horizontal cell responses are shaped at the photoreceptor ribbon synapse. Eur J Neurosci 27:2575-2586. CrossRef Medline

Carr CE, Konishi M (1990) A circuit for detection of interaural time differences in the brain stem of the barn owl. J Neurosci 10:3227-3246. Medline

Contini D, Zampini V, Tavazzani E, Magistretti J, Russo G, Prigioni I, Masetto S (2012) Intercellular $\mathrm{K}(+)$ accumulation depolarizes type I vestibular hair cells and their associated afferent nerve calyx. Neuroscience 227:232-246. CrossRef Medline

Demêmes D, Lleixa A, Dechesne CJ (1995) Cellular and subcellular localization of AMPA-selective glutamate receptors in the mammalian peripheral vestibular system. Brain Res 671:83-94. CrossRef Medline

DiGregorio DA, Nusser Z, Silver RA (2002) Spillover of glutamate onto synaptic AMPA receptors enhances fast transmission at a cerebellar synapse. Neuron 35:521-533. CrossRef Medline

DiGregorio DA, Rothman JS, Nielsen TA, Silver RA (2007) Desensitization properties of AMPA receptors at the cerebellar mossy fiber granule cell synapse. J Neurosci 27:8344-8357. CrossRef Medline

Dulon D, Safieddine S, Jones SM, Petit C (2009) Otoferlin is critical for a highly sensitive and linear calcium-dependent exocytosis at vestibular hair cell ribbon synapses. J Neurosci 29:10474-10487. CrossRef Medline

Eatock RA, Songer JE (2011) Vestibular hair cells and afferents: two channels for head motion signals. Annu Rev Neurosci 34:501-534. CrossRef Medline

Farris HE, Wells GB, Ricci AJ (2006) Steady-state adaptation of mechanotransduction modulates the resting potential of auditory hair cells, providing an assay for endolymph [Ca2+]. J Neurosci 26:12526-12536. CrossRef Medline

Favre D, Sans A (1979) Morphological changes in afferent vestibular hair cell synapses during the postnatal development of the cat. J Neurocytol 8:765-775. CrossRef Medline

Fernández C, Goldberg JM (1971) Physiology of peripheral neurons innervating semicircular canals of the squirrel monkey: II. Response to sinusoidal stimulation and dynamics of peripheral vestibular system. J Neurophysiol 34:661-675. Medline

Fernández C, Baird RA, Goldberg JM (1988) The vestibular nerve of the chinchilla. I. Peripheral innervation patterns in the horizontal and superior semicircular canals. J Neurophysiol 60:167-181. Medline

Glowatzki E, Fuchs PA (2002) Transmitter release at the hair cell ribbon synapse. Nat Neurosci 5:147-154. CrossRef Medline

Goldberg JM (1996) Theoretical analysis of intercellular communication between the vestibular type I hair cell and its calyx ending. J Neurophysiol 76:1942-1957. Medline

Goldberg JM (2000) Afferent diversity and the organisation of central vestibular pathways. Exp Brain Res 130:277-297. CrossRef Medline

Goutman JD, Glowatzki E (2007) Time course and calcium dependence of transmitter release at a single ribbon synapse. Proc Natl Acad Sci U S A 104:16341-16346. CrossRef Medline

Grant L, Yi E, Glowatzki E (2010) Two modes of release shape the postsynaptic response at the inner hair cell ribbon synapse. J Neurosci 30:4210 4220. CrossRef Medline

Highstein SM, Holstein GR, Mann MA, Rabbitt RD (2014) Evidence that protons act as neurotransmitters at vestibular hair cell-calyx afferent synapses. Proc Natl Acad Sci U S A 111:5421-5426. CrossRef Medline

Hires SA, Zhu Y, Tsien RY (2008) Optical measurement of synaptic glutamate spillover and reuptake by linker optimized glutamate-sensitive fluorescent reporters. Proc Natl Acad Sci U S A 105:4411-4416. CrossRef Medline

Holt JC, Chatlani S, Lysakowski A, Goldberg JM (2007) Quantal and nonquantal transmission in calyx-bearing fibers of the turtle posterior crista. J Neurophysiol 98:1083-1101. CrossRef Medline

Horwitz GC, Risner-Janiczek JR, Holt JR (2014) Mechanotransduction and hyperpolarization-activated currents contribute to spontaneous activity in mouse vestibular ganglion neurons. J Gen Physiol 143:481-497. CrossRef Medline

Hurley KM, Gaboyard S, Zhong M, Price SD, Wooltorton JR, Lysakowski A, Eatock RA (2006) M-like K+ currents in type I hair cells and calyx afferent endings of the developing rat utricle. J Neurosci 26:10253-10269. CrossRef Medline

Isaacson JS (1999) Glutamate spillover mediates excitatory transmission in the rat olfactory bulb. Neuron 23:377-384. CrossRef Medline

Kennedy MB (1997) The postsynaptic density at glutamatergic synapses. Trends Neurosci 20:264-268. CrossRef Medline

Khimich D, Nouvian R, Pujol R, Tom Dieck S, Egner A, Gundelfinger ED, Moser T (2005) Hair cell synaptic ribbons are essential for synchronous auditory signalling. Nature 434:889-894. CrossRef Medline

Kössl M, Vater M (1985) The cochlear frequency map of the mustache bat, pteronotus parnellii. J Comp Physiol A 157:687-697. CrossRef Medline

Kullmann DM, Erdemli G, Asztély F (1996) LTP of AMPA and NMDA receptor-mediated signals: evidence for presynaptic expression and extrasynaptic glutamate spill-over. Neuron 17:461-474. CrossRef Medline

Lasker DM, Han GC, Park HJ, Minor LB (2008) Rotational responses of vestibular-nerve afferents innervating the semicircular canals in the C57BL/6 mouse. J Assoc Res Otolaryngol 9:334-348. CrossRef Medline Li GL, Keen E, Andor-Ardó D, Hudspeth AJ, von Gersdorff H (2009) The 
unitary event underlying multiquantal EPSCs at a hair cell's ribbon synapse. J Neurosci 29:7558-7568. CrossRef Medline

Liberman LD, Wang H, Liberman MC (2011) Opposing gradients of ribbon size and AMPA receptor expression underlie sensitivity differences among cochlear-nerve/hair-cell synapses. J Neurosci 31:801-808. CrossRef Medline

Liberman MC (1980) Morphological differences among radial afferent fibers in the cat cochlea: an electron-microscopic study of serial sections. Hear Res 3:45-63. CrossRef Medline

Lim R, Kindig AE, Donne SW, Callister RJ, Brichta AM (2011) Potassium accumulation between type I hair cells and calyx terminals in mouse crista. Exp Brain Res 210:607-621. CrossRef Medline

Lysakowski A, Goldberg JM (2008) Ultrastructural analysis of the cristae ampullares in the squirrel monkey (Saimiri sciureus). J Comp Neurol 511:47-64. CrossRef Medline

Magee JC, Cook EP (2000) Somatic EPSP amplitude is independent of synapse location in hippocampal pyramidal neurons. Nat Neurosci 3:895903. CrossRef Medline

Matsubara A, Takumi Y, Nakagawa T, Usami S, Shinkawa H, Ottersen OP (1999) Immunoelectron microscopy of AMPA receptor subunits reveals three types of putative glutamatergic synapse in the rat vestibular end organs. Brain Res 819:58-64. CrossRef Medline

McLean WJ, Smith KA, Glowatzki E, Pyott SJ (2009) Distribution of the Na, K-ATPase alpha subunit in the rat spiral ganglion and organ of corti. J Assoc Res Otolaryngol 10:37-49. CrossRef Medline

Meredith FL, Benke TA, Rennie KJ (2012) Hyperpolarization-activated current (I (h)) in vestibular calyx terminals: characterization and role in shaping postsynaptic events. J Assoc Res Otolaryngol 13:745-758. CrossRef Medline

Oikonomou KD, Short SM, Rich MT, Antic SD (2012) Extrasynaptic glutamate receptor activation as cellular bases for dynamic range compression in pyramidal neurons. Front Physiol 3:334. CrossRef Medline

Oliet SH, Piet R, Poulain DA (2001) Control of glutamate clearance and synaptic efficacy by glial coverage of neurons. Science 292:923-926. CrossRef Medline

Otis TS, Wu YC, Trussell LO (1996) Delayed clearance of transmitter and the role of glutamate transporters at synapses with multiple release sites. J Neurosci 16:1634-1644. Medline

Ramachandran R, Lisberger SG (2006) Transformation of vestibular signals into motor commands in the vestibuloocular reflex pathways of monkeys. J Neurophysiol 96:1061-1074. CrossRef Medline

Rennie KJ, Ashmore JF (1993) Effects of extracellular ATP on hair cells isolated from the guinea-pig semicircular canals. Neurosci Lett 160:185189. CrossRef Medline

Rennie KJ, Streeter MA (2006) Voltage-dependent currents in isolated vestibular afferent calyx terminals. J Neurophysiol 95:26-32. CrossRef Medline

Rüsch A, Lysakowski A, Eatock RA (1998) Postnatal development of type I and type II hair cells in the mouse utricle: acquisition of voltage-gated conductances and differentiated morphology. J Neurosci 18:7487-7501. Medline

Rutherford MA, Chapochnikov NM, Moser T (2012) Spike encoding of neurotransmitter release timing by spiral ganglion neurons of the cochlea. J Neurosci 32:4773-4789. CrossRef Medline
Ryugo DK, Fekete DM (1982) Morphology of primary axosomatic endings in the anteroventral cochlear nucleus of the cat: a study of the endbulbs of held. J Comp Neurol 210:239-257. CrossRef Medline

Sadeghi SG, Chacron MJ, Taylor MC, Cullen KE (2007) Neural variability, detection thresholds, and information transmission in the vestibular system. J Neurosci 27:771-781. CrossRef Medline

Sätzler K, Söhl LF, Bollmann JH, Borst JG, Frotscher M, Sakmann B, Lübke JH (2002) Three-dimensional reconstruction of a calyx of held and its postsynaptic principal neuron in the medial nucleus of the trapezoid body. J Neurosci 22:10567-10579. Medline

Scanziani M, Salin PA, Vogt KE, Malenka RC, Nicoll RA (1997) Use-dependent increases in glutamate concentration activate presynaptic metabotropic glutamate receptors. Nature 385:630-634. CrossRef Medline

Schmidt RS (1963) Independence of the endocochlear potential in homeotherms. J Gen Physiol 47:371-378. CrossRef Medline

Schnee ME, Castellano-Muñoz M, Ricci AJ (2013) Response properties from turtle auditory hair cell afferent fibers suggest spike generation is driven by synchronized release both between and within synapses. J Neurophysiol 110:204-220. CrossRef Medline

Singer JH, Lassová L, Vardi N, Diamond JS (2004) Coordinated multivesicular release at a mammalian ribbon synapse. Nat Neurosci 7:826-833. CrossRef Medline

Smith CA, Davis H, Deatherage BH, Gessert CF (1958) DC potentials of the membraneous labyrinth. Am J Physiol 193:203-206. Medline

Songer JE, Eatock RA (2013) Tuning and timing in mammalian type I hair cells and calyceal synapses. J Neurosci 33:3706-3724. CrossRef Medline

Szapiro G, Barbour B (2007) Multiple climbing fibers signal to molecular layer interneurons exclusively via glutamate spillover. Nat Neurosci 10: 735-742. CrossRef Medline

Trussell LO, Zhang S, Raman IM (1993) Desensitization of AMPA receptors upon multiquantal neurotransmitter release. Neuron 10:1185-1196. CrossRef Medline

Wadiche JI, Jahr CE (2001) Multivesicular release at climbing fiberPurkinje cell synapses. Neuron 32:301-313. CrossRef Medline

Wooltorton JR, Gaboyard S, Hurley KM, Price SD, Garcia JL, Zhong M, Lysakowski A, Eatock RA (2007) Developmental changes in two voltage-dependent sodium currents in utricular hair cells. J Neurophysiol 97:1684-1704. CrossRef Medline

Yamada KA, Rothman SM (1992) Diazoxide blocks glutamate desensitization and prolongs excitatory postsynaptic currents in rat hippocampal neurons. J Physiol 458:409-423. Medline

Yamashita M, Ohmori H (1990) Synaptic responses to mechanical stimulation in calyceal and bouton type vestibular afferents studied in an isolated preparation of semicircular canal ampullae of chicken. Exp Brain Res 80:475-488. Medline

Yang A, Hullar TE (2007) Relationship of semicircular canal size to vestibular-nerve afferent sensitivity in mammals. J Neurophysiol 98: 3197-3205. CrossRef Medline

Yi E, Roux I, Glowatzki E (2010) Dendritic HCN channels shape excitatory postsynaptic potentials at the inner hair cell afferent synapse in the mammalian cochlea. J Neurophysiol 103:2532-2543. CrossRef Medline 